\title{
Public Health Nursing for Southern Blacks in the Depression Era
}

\author{
LaShanda Brown Sell \\ Winston-Salem, North Carolina
}

BSN, University of North Carolina-Chapel Hill, 1994

MSN, Duke University, 2005
Final Dissertation presented to the Graduate Faculty
of the University of Virginia for the Degree of
Doctor of Philosophy

March, 2016

\author{
School of Nursing \\ University of Virginia
}

Barbra Mann Wall, PhD, RN, FAAN

Mary Gibson, $\mathrm{PhD}, \mathrm{RN}$

Pamela Kulbock, DNSc, RN, PHCNS-BC, FAAN

Preston Reynolds, MD, PhD, MACP 


\section{Chapter 1: Purpose and Methodology}

Today, 20 percent of black Americans are uninsured, under insured or lack access to health care, compared to only 11 percent of white Americans. ${ }^{1}$ In North Carolina the problem of disparities in health between blacks and whites is typical of southern states in the United States. Rates of chronic and communicable disease in African Americans surpass their white counterparts in North Carolina in every category: diabetes rates per 1,000 live births are 44.8 among blacks, 17.5 among whites; heart disease is 209.1 among blacks, 176.1 among whites; syphilis is 27.0 among blacks, 2.5 among whites, and HIV is 62.8 among blacks, 6.3 among whites in North Carolina. ${ }^{2}$ Many research dollars and hours each year go towards addressing disparities in health outcomes, but few focus on the historical influence on the current situation.

The problem of access to health care and poverty among rural blacks throughout the United States is not a new problem. A historical overview of health care for blacks in the southern United States in the 1930s can provide insight into the problems that exist today. This insight has the potential to shape current and future policies and interventions to address disparities in access to quality health care. This historical research focuses on the problem of health disparities and the social determinants of health among blacks in early $20^{\text {th }}$ century North

Carolina. It shows that black nurses were absolutely essential to public health care in North Carolina, but experienced employment disparities because they were black. However they were essential in gaining the trust of the local black population. 
Purpose

The purpose of this dissertation research is to describe and analyze the impact of public health nursing on the black community in rural Forsyth and Durham counties of North Carolina in the 1930s. The research questions that guided the investigation include: (1) Were there unique barriers to health care for blacks in the South in this era? (2) What was the role of public health nurses in the delivery of health care to poor blacks living in rural North Carolina? (3) How did the intersection of race, class and gender impact a nurse's ability to provide quality nursing care to marginalized groups?

\section{Research Design \& Methodology}

This research used traditional historical methods with a social history framework, exploring nursing issues and how they were shaped by the social events of the 1930s. It includes a discussion of different racial and class groups within rural North Carolina, as well as political, social, and economic events that shaped the nurses' work. Issues of race, class and gender are emphasized. ${ }^{3}$ The use of a social history framework provides the opportunity to both examine the issues of health care for the underrepresented portion of the population-poor blacks, and examine the experience of black nurses themselves. ${ }^{4}$ Blacks living in the south represent those living on society's margins. ${ }^{5}$

Susan Reverby and David Rosner, in Health Care in America: Essays in Social History, attempted to link social and medical history and asserted that a historical analysis should examine the professionals' definition of health and disease as well as the lay members' 
definition. This work will explore nurses' views of health compared with black North Carolinians' views of health. Reverby and Rosner also challenged social histories to explore relationships, and this work examines the relationship between nurses, doctors, residents, and employers, and how these dynamic relationships impacted health care. ${ }^{6}$

The research data phase of this project was guided by historian Mary Sarnecky's stepwise method of identification, location, examination, synthesis and finally application. ${ }^{7}$ The first step in Sarnecky's method of inquiry is determination of the focus of inquiry. The next step, identification and location of data sources, is followed by examination of the data collected for validity and reliability. The fourth step, data synthesis, includes organization and analysis of the data. And the final step of historical inquiry is application of results in a way that demonstrates relevance of past issues to current and future health trends. ${ }^{8}$

\section{Focus of Inquiry}

The primary focus of this historical inquiry was an examination of the public health nursing role caring for blacks in rural North Carolina. Evaluating the role of black public health nurses as well as white nurses caring for rural blacks as a special focus helped to narrow the broad topic of public health nursing, and highlight one particular area for innovative nursing care. Narrowing the focus of public health nursing to this particular setting also aided the manageability of the study, as well as provided a unique focus that has not been well documented in the literature. ${ }^{9}$ In addition, this analysis will incorporate the social, cultural, political, and economic climate of North Carolina in the 1930s, a period of racial segregation, gender inequality, class differences, and general poor health for rural North Carolinians. ${ }^{10}$ 
Framework

The use of social history framework for this study allowed the researcher to question and interpret the data from the perspective of various groups within society, incorporating the impact of race, class, and gender in the analysis. ${ }^{11}$ In 1930s North Carolina, the impact of race on access to health care cannot be overlooked. Jim Crow laws enforcing racial segregation were enforced, and blacks had little access to care. In fact, an elite class of white North Carolinians enforced laws that disenfranchised blacks, women, and working class whites. This era was a complex and challenging time for all marginalized groups, and using social history framework provided a thorough interpretation of the data from a grass roots perspective.

\section{Data Sources}

Primary data sources included materials from the following archives at the University of North Carolina's Wilson Library: the Southern Oral History Collection, North Carolina Collection, and Southern Historical Collection. These collections included oral histories conducted by Jane Abernathy Plyler, who interviewed six white and black public health nurses who practiced during the 1930s. The Southern Oral History Collection also included the Federal Writers Project transcripts, a collection of interviews done in the 1970s of ordinary citizens living in the early $20^{\text {th }}$ century. This collection is an example of historical data collected from a social history framework that explores the lives of everyday people, including marginalized blacks living and working in rural North Carolina.

Data were collected from Duke University archives, which house the records of the North Carolina Mutual Life Insurance Company. The state archives in Raleigh, NC were visited since 
they hold general public records of the health and welfare of North Carolinians. The visit to the state archives targeted health reports from Forsyth and Durham counties' health departments, as well as nursing visit records.

Data were also collected from the Forsyth County public library's North Carolina Room that features Winston-Salem history. The North Carolina Room provides photographs, newspaper articles, and maps of Forsyth County, Winston-Salem. Preliminary data were collected from the Malloy Jordan East Winston Heritage Center specific to Forsyth County's history. The Heritage Center houses historical photographs of African Americans, the Shades of Forsyth Oral History collection, and the Strings of Pearl Storytellers' collection. The digital archive of Forsyth County, www.digitalforsyth.org, was explored for photographs collected during the 1930 s.

\section{Data Exploration (Criticism of Sources)}

A necessary process during and after data collection is evaluation of the data collected to ensure it is authentic, valid, reliable, and credible. ${ }^{12}$ Primary data collected were analyzed with objectivity using a high level of self-awareness to limit bias in interpreting findings. The researcher also used a considerable amount self-reflection to sort out the extent to which knowledge and interpretation affected data interpretation. ${ }^{13}$

All documents were examined for reliability related to their truthfulness, trustworthiness and credibility taking into account the time period, and whether there are any conflicting facts within the data. ${ }^{14}$ External criticism was also used to ensure authenticity of the data collected. A combination of primary sources were used to broaden perspective and provide a more complete historical representation. 


\section{Data Management}

An initial comprehensive review of the literature was done to explore the proposed topic and develop research questions. An ongoing process of literature review occurred throughout the process of analyzing both primary and secondary sources. The process of data immersion drives the research questions and data collection process, and according to historian Sandra Lewenson, this process continually feeds the ongoing process of data immersion. ${ }^{15}$

The historical research process involved a circuitous interpretation of variables from multiple perspectives. According to nurse historian Patricia D'Antonio, this manipulation of variables should occur using four key concepts. First, variables interact equally so that no one variable is given more weight than another. Second, variables are manipulated within the context of a fixed time and place. In addition, a variable is viewed as context specific to consider what would be the value of an event in a specific place and moment in history. And fourth, the variable is assessed along a continuum of "admirable to abominable." ${ }^{16}$ In this study, the variables of race, class, and gender were given equal consideration as they related to the health care provided by rural public health nurses in North Carolina.

In an effort to optimize ongoing data management, an organized strategy was initiated at the onset of preliminary data collection. Historian Lewenson emphasizes the importance of an early organizing strategy to protect data that may be insignificant early in the research process, but proves to be vital in connecting events later. ${ }^{17}$ Therefore, documents were categorized by topic and chronology, then stored digitally with a paper copy as backup. Primary data were further organized in chronological order, labeled by theme and headings that facilitated access 
during the analytic process. Any notes taken about primary data sources were scanned and stored in digital format, as well as filed within related themes and headings. Finally, primary source data were labeled with a full reference for citation and retrieval.

\section{Data Analysis}

Primary source data were analyzed systematically for themes during the data immersion process. Immersion required multiple readings of the data in order to assign codes and themes. ${ }^{18}$ During the coding process, particular phrases or quotes were extracted to assist with identification of emerging themes within the data. ${ }^{19}$

The data synthesis and analysis phases resulted in a historical argument supported by a chronological narrative that substantiates the supporting data. The historical argument was developed throughout the course of data immersion and analysis, and is presented here in the form of a narrative told in chronological order from reemployment of public health nurses through New Deal funds to the establishment of nurses in the community addressing the issues of communicable disease, school health, and maternal child health. ${ }^{20}$

\section{Ethical Conduct of Research}

This research was conducted using official standards of data collection, interpretation, and reporting. Ethical principles guiding this research towards accurately reporting the data, providing for confidentiality of the research subjects, and use of historical context will be used to analyze the truth in data. ${ }^{21}$ Research was conducted in adherence to all legal and consensual rules of each archival facility used during the study. 
Since nursing historical research utilizes documents that may contain identifying patient information, consideration will be given to the Health Insurance Portability and Accountability Act (HIPPA). Furthermore, compliance with Institutional Review Board (IRB) guidelines required that a protocol be submitted to the University of Virginia IRB for the Social and Behavioral Sciences (SBS) prior to data collection. IRB exemption was obtained (reference to Project \#2014-0439-00) for the use of both primary archival materials as well as transcripts for oral histories taken in the 1970s.

Strengths \& Weaknesses of the Proposed Study

The principal investigator's prior experience with public health nursing represented both a strength and a possible weakness to the study. Public health experience was a strength because it provided the principal investigator an understanding of the role of the public health nurse working in various settings providing care for underserved populations. Familiarity with the gaps in care for poor, rural residents of North Carolina guided many of the research questions. In an attempt to remain objective, however, discussion of the data and drafts of the manuscripts were reviewed with the committee.

Research Timeline

\begin{tabular}{|l|l|l|l|}
\hline Proposal Defense & Data Collection & Data Analysis & Dissertation Defense \\
\hline January 2014 & $1 / 14$ to $1 / 15$ & $1 / 15$ to $1 / 16$ & March 2016 \\
\hline
\end{tabular}

Chapter Overview

Chapter Two is a historical overview of health care in the South, public health nursing in North Carolina, and the social, political and economic climate in which this study takes place. 
The chapter focuses on the historical background of the American South during the Progressive era and early $20^{\text {th }}$ century. The political, social and economic climate of southern states compared to Northern states is discussed. Through this review of the secondary history literature on the American South, the public health status of southerners, blacks in particular, are examined in relation to the race and class divisions in the south. The chapter also reviews public health nursing in the 1930s. This review highlights the public health issues faced by poor, rural North Carolinians, as well as the shortage of health care providers during this time period. In addition, the various roles and functions of public health nurses in $\mathrm{NC}$ are discussed.

Chapter Three discusses the impact of public health nursing on rural blacks. Using case study of oral histories, the chapter describes and analyzes the role of the public health nurse who provided care in the homes and schools of rural black North Carolinians in the 1930s. The black public health nursing role in the community is analyzed to determine the effectiveness of this role in improving the health of disadvantaged minorities.

Chapter Four analyzes the impact of school nursing and the impact of white nurses on the black community. This chapter focuses on the value of both black and white public health nurses on health education in rural North Carolina. The chapter compares the public health nurses' roles and influence in the community relative to the nurse's race to explore whether race was a factor in how care was delivered and received.

Chapter Five provides conclusions drawn from data analysis. 
${ }^{1}$ The United States Census Bureau, April 7, 2013,
http://www.census.gov/hhes/www/hlthins/data/incpovhlth/2010/highlights.html.

${ }^{2}$ North Carolina Vital Health Facts: Population \& Health Data by Race and Ethnicity.

${ }^{3}$ Cynthia Connolly, "Beyond Social History: New Approaches to Understanding the State of and State in Nursing History,” Nursing History Review 12 (2004): 5-24.

${ }^{4}$ Sandra Lewenson and Eleanor Krohn Herrman, Capturing Nursing History: A Guide to Historical Methods in Research (New York: Springhouse Publishers, 2007).

${ }^{5}$ Cynthia Connolly, "Beyond social history."

${ }^{6}$ Connolly, "Beyond social history;" See also, Susan Reverby and David Rosner, "Beyond the Great Doctors", in Health Care in America: Essays in Social History, (Philadelphia: Temple University Press, 1979): 4. Dr. Connolly notes that although Reverby and Rosner's linking of social and medical history was initially controversial it is considered classic today.

${ }^{7}$ Mary T. Sarnecky, "Historiography: A Legitimate Research Methodology for Nursing," Advances in Nursing Science 12 (1990): 3-5.

${ }^{8}$ Mary T. Sarnecky, "Historiography: A Legitimate Research Methodology for Nursing.”

${ }^{9}$ Alma C. Haupt, "Thirty Years of Pioneering: In Public Health Nursing," The American Journal of Nursing, 39 (1939): 619-626; Margaret Morton and Edna Roberts, Celebrating Public Health Nursing: Caring for Mississippi's Communities With Courage and Compassion 1920-1993, Updated Through 1998: A Synopsis (Published by Mississippi State Department of Health, year unknown).

${ }^{10}$ Sandra B. Lewenson, "Historical research method," in Qualitative Research in nursing: Advancing the Humanistic Imperative (Philadelphia: Lippincott, Williams \& Wilkins, 2007), 259.

${ }^{11}$ Joy Buck, "Using frameworks in historical research," in Capturing Nursing History: A Guide to Historical Methods in Research (New York: Springer Publishing Company, 2008), 58.

${ }^{12}$ Brigid Lusk, "Historical methodology for nursing research," Image: Journal of Nursing Scholarship 29, no. 4 (1997): 355-359.

${ }^{13}$ Sandra B. Lewenson, "Historical research method," in Qualitative Research in nursing: Advancing the Humanistic Imperative, ed Helen J. Streubert Speziale and Dona Rinaldi Carpenter (Philadelphia: Lippincott, Williams \& Wilkins, 2007), 259.

${ }^{14}$ Jacques Barzun and Henry F. Graff, The Modern Researcher.

${ }^{15}$ Lewenson and Herrman, Capturing Nursing History.

${ }^{16}$ Patricia D'Antonio, “Conceptual and methodological issues," in Capturing Nursing History: A Guide to Historical Methods in Research, ed Sandra B Lewenson and Eleanor Krohn Herrmann (New York: Springer Publishing Company, 2008), 11-22; John Lewis Gaddis, The Landscape of History: How Historians Map the Past (New York: Oxford Press, 2002). 
${ }^{17}$ Lewenson, "Historical research method."

${ }^{18}$ Marlene Zichi Cohen, David Kahn and Richard H. Steeves, Hermeneutic Phenomenological Research: A Practical Guide for Nurse Researchers (London: Sage Publications, Inc., 2000), 76-82.

${ }^{19}$ Lewenson, "Historical research method."

${ }^{20}$ Lewenson, "Historical research method;" D'Antonio, "Conceptual and methodological issues."

${ }^{21}$ Nettie Birback, Janie Brown, and Wanda Hiestand, "Ethical Guidelines for the nurse historian," American Association for the History of Nursing Bulletin, 38 (1993): 4. 


\section{Chapter 2: Historical Overview of Public Health Nursing in the Rural South}

The purpose of this dissertation is to explore the history of public health nursing in the rural South during the 1920s and 1930s. Specifically, the study focuses on rural Eastern North Carolina, exploring the dynamics of rural public health nursing, the effect of the economic crisis on public health, and the additional barriers to health care for blacks related to utilization of services, education, and race relations. The chapter highlights challenges to the health and wellbeing of blacks living in the rural South during this period in history and the role of the public health movement that capitalized on nurses to meet the social welfare needs of blacks. As governments across the world today struggle with what policies to take toward the social determinants of health, it is illuminating to note that their concerns have been played out historically in numerous contexts and geographic areas. ${ }^{22}$

This dissertation argues that black nurses were absolutely essential to public health for blacks in North Carolina. It illuminates the ways race, socioeconomic class, and region worked together to shape health care in the South. Within a context of established racism, social and environmental conditions were also important influences on health in rural North Carolina. Both black and white public health nurses addressed these issues as they worked to improve the health of rural blacks in the region.

In order to understand the health situation of blacks in Eastern North Carolina and the work of nurses in the region, it is important to understand the context in which the poor health of rural blacks occurred in the South in general. This chapter summarizes the economic challenges of North Carolina, the major racial issues, the difficulties blacks had in obtaining care, and attempts to rectify that situation. 
Progressive Era

Progressivism in the majority of the United States was a movement that included local and state improvements in health and welfare legislation, food and drug standards, and women's suffrage.

However, the South, infused with poverty, racism and despair was far removed from the country's efforts toward improvement. Instead, the region's politicians enacted a series of measures aimed at disenfranchisement of blacks in order to maintain control over the black population. Southern Progressives lagged behind the growth of the remainder of the country in their futile attempt to modernize the region while holding fast to southern tradition. ${ }^{23}$ In fact, the South remained virtually unchanged over 50 years despite spokesmen's claims of parallel progression with the North. ${ }^{24}$

The health of blacks in rural Eastern North Carolina is a case where the effects of both race and poverty on health were clear. The beginning of the $20^{\text {th }}$ century marked a period of significant social change in the South known as Southern Progressivism. Between the years 1900 and 1918, reformists attempted to confront the political, social, and moral problems that faced Americans as the country moved into the $20^{\text {th }}$ century. This period of social change, complete with race, class, and gender inequalities, resulted from a clash between Northern reformists wanting to restructure governance into a more paternalistic relationship between local communities, the national government, and southern traditionalists who favored participatory democracy on a local level and generally viewed social problems more passively. Indeed, southerners, long wedded to the idea of "states' rights," valued localism and opposed outside interference that threatened freedom from government intrusions. ${ }^{25}$ Thus Northern reformists met resistance in trying to initiate programs that they thought would protect the most vulnerable. ${ }^{26}$

The culture of the South, defined by geographic and social isolation, bred loyalty to neighborhood and community, often resulting in unfriendliness towards outsiders. Rural sociologist Eugene Branson observed in 1916 that North Carolina was "far removed from socialism in any sense, good or bad... [and was] but a hair's breadth away from individualism, raw, raucous and unorganizable."27 Indeed, long- 
standing tensions between the North and the South following the Civil War persisted, as well as a general resistance to change on the part of many rural white southerners. ${ }^{28}$ This led to great difficulties for any organized program of public health.

Agriculture and Economy in North Carolina

North Carolina is a particularly significant state to study because its agricultural development lagged behind that of other states due to the prevailing system of farm tenancy. In the early 1920s, North Carolina's economy was based on agriculture, tobacco, and textile manufacturing, rural North Carolina was primarily agriculture. In the North and West, tenant farming grew to be a "capitalistic enterprise," while tenancy in the South was seen as an "evil" that exploited the poor man — both black and white. ${ }^{29}$ Landowners had a clear and unfair advantage that was addressed by North Carolina Governor Thomas Bickett in 1922:

Every consideration of progress and safety urges us to employ all wise and just measures to get our lands into the hands of the many and forestall that most destructive of all monopolies - the monopoly of the soil. ${ }^{30}$

The crop-lien system of tenant farming left tenants overly dependent on credit from landlords and supply storeowners throughout the year. When annual fall crop payments occurred, the tenant farmer was often too deeply in debt to see much profit. For blacks, these economic problems were compounded by racial disparities: the average annual cash income for white farm owners was $\$ 770$, while for black owners it was $\$ 515$; for white tenants it was $\$ 365$, and for black tenants, the lowest paid, it was $\$ 209 .{ }^{31}$

\section{Poverty in North Carolina}

For both blacks and whites, farms in North Carolina produced mostly cash crops (cotton, tobacco, and corn) that, without rotation, depleted the soil and negatively impacted the state's economy. Meanwhile little time and space was devoted to foods for home consumption (potatoes, poultry, and 
pork). This lack of food production directly impacted the state's poverty crisis as well as the health of its most poverty-stricken residents. In 1922, the percent of food produced for home consumption on farms in the central part of the state was 84 percent for white tenants but only 60 percent for black tenants. ${ }^{32}$ The combination of lower cash incomes, lower personal-use food production, and higher debt left rural blacks and whites in an ill-fated scenario of inevitable poverty and poor health. The health and well-being of many rural southerners was directly impacted by the agricultural economy of the 1920s and the economic depression of the 1930s. It was particularly so for southern blacks, often seen as the "lowest" class of southern society.

Rural areas were hardest hit during the late 1920s and early 1930s due to drought, poor farming conditions, decreased government subsidies, and the poor economic condition of the Great Depression. ${ }^{33}$ The majority of black Americans lived in the South and inhabited rural rather than urban areas. No particular diseases seemed to be more prevalent in one group compared to others until social factors of education, hygiene, access to care, and income were considered, at which point blacks suffered from death and disease disproportionately. Illness in blacks seemed to be more significantly influenced by disparities in income and access to care. ${ }^{34}$

One example of Northern philanthropy that was meant to enhance the health of poor whites and blacks was the hookworm program, begun in 1910 by the Rockefeller Foundation with a donation from John D. Rockefeller, Sr. The Rockefeller Sanitary Commission for the Elimination of Hookworm Disease launched an anti-hookworm campaign in the South backed by a $\$ 1$ million startup gift from Rockefeller. Initially the commission focused on educating doctors and teachers, and shifted to treatment using a traveling dispensary model. ${ }^{35}$ The travelling dispensary found success in bring needed treatment to the communities. Over a four year period, the rate of infection was cut in half in North Carolina. ${ }^{36}$

While progress in urban sanitation was a result of an organized community effort, the responsibility of rural sanitation efforts was a result of public health and sanitation workers raising awareness and interest in the benefits of providing a safe water supply and adequate sanitary facilities in both homes and schools. ${ }^{37}$ Public health and sanitation workers were devoted to improving the equipment 
available to improve the water supply quality designing better wells and sisterns for use in the communities. From 1910-1920, the United States Public Health Service conducted surveys and led programs to treat and install 2.9 million sanitary privies in 38 states. $^{38}$

Black families, half of whom were employed in agriculture as farm tenants or laborers, were especially vulnerable to the shifting conditions in agriculture. In November 1932, a prominent white planter of Pitt County in North Carolina wrote: "A good many Negroes [sic] have lived in farm houses rent free this year and in most cases have been given land for garden. They have lived hard. They are in much worse condition than a year ago." 39 The resulting impact of the economic depression on already difficult living conditions was a lower standard of living, resulting in inadequate food, clothing, shelter, health, and morale for blacks living in the rural South. While the efforts to educate poor, rural blacks were important to address the health concerns of that time, the major problem of economic poverty remained the unmovable force and "greatest cause of Negro sickness and death." 40 In this arena, both black and white public health nurses became the predominant formal health care providers as they dealt with health issues that especially related to poverty.

Racism in the South

Throughout the South, the economic barrier to adequate health care was intensified by segregation. After Plessy v Ferguson legalized segregation in 1896, this federal ruling along with locallycreated Jim Crow laws went into effect. State and local laws enforced a system of segregation limiting blacks from access to public facilities such as hospitals, schools, restaurants, and transportation. ${ }^{41}$ As well, Jim Crow laws and disenfranchisement of blacks at the turn in the $20^{\text {th }}$ century effectively took away voting rights from blacks by forcing them to pass literacy tests. ${ }^{42}$ Thus, with an illiteracy rate much higher than their white counterparts, blacks saw education as a ticket out of the bondage imposed by disenfranchisement. ${ }^{43}$ White upper-class male supremacy, however, put women, working class whites, and black women and men at a disadvantage with little power to bargain for their own rights. As a result, 
in order to overcome barriers created by a society marked by poor race relations and strict class distinctions, blacks had to have both dedication and perseverance. ${ }^{44}$

In addition to the barriers of race and class, commonly-held beliefs about blacks influenced their ability to move up the economic ladder. In the early 1900s, there was the common belief that blacks were inferior and uneducable. Jim Crow laws reinforced the sentiment that the white race was supreme and successfully disenfranchised blacks in areas of government, voting, housing, employment, and education. ${ }^{45}$ Medical care was also affected. Michael Davis, chairman for the Committee on Research in Medical Economics, reinforced this observation:

In the South, race presents definitive barriers to the use of certain services particularly in institutions; and the medical care of the Negro in the South has the further characteristic that it is largely a problem of rural areas. ${ }^{46}$

In the Jim Crow South in the 1920s and 1930s, the theory of racial inferiority provided another reason for disparities in disease incidence. Frederick Hoffman, a health statistician from Prudential Life Insurance Company used statistics from the insurance company to research the incidence of disease among blacks and whites to prove that blacks were uninsurable. Hoffman's work, done on behalf of Prudential in response to state legislation banning discrimination against blacks, was a compilation of statistics, eugenic theory, observation, and speculation that blacks were not only biologically inferior but also barriers to progress. ${ }^{47}$ Whites at the time used this argument to support their hands off approach to public health education for those they viewed as genetically inferior. However, W.E.B. Du Bois, American sociologist, historian, and civil rights activist, countered this view in The Health Physique of the Negro American arguing that environment played a greater role in morbidity and mortality rates than genetics. For example, hookworm, a disease of poverty and deficiency, prevailed in the South, affecting blacks more than whites because rural blacks lived, worked, and played close to the land. They were poorly clothed and without shoes and proper sanitation. ${ }^{48}$ 
One of the more lasting effects of Jim Crow laws on rural North Carolinians was known as the poverty-segregation complex. Although debates intensified in the 1960s, North Carolina historian Jim Leloudis describes issues of poverty and segregation that exacerbated as early as the $1920 \mathrm{~s} .{ }^{49}$ North Carolina tobacco and textile industries had been known internationally, and they positioned North Carolina to be a productive leader in the United States in the early $20^{\text {th }}$ century. But because many white North Carolinians were unwilling to let go of their southern ideals of black inferiority, they continued to build industries on the premise of cheap labor. While white southerners valued democracy, individualism, and Christian charity, this was not the reality for blacks living in the South. ${ }^{50}$

Du Bois, author of The Souls of Black Folk, described the problem of the twentieth century as relative to the social and political divisions made by our country based on race. ${ }^{51}$ Du Bois further defines the challenges of racism for blacks as being complicated by challenges of poverty for all. Du Bois' statement was true of North Carolina as it faced a second reconstruction and an opportunity to redefine race relations in the state in the early $20^{\text {th }}$ century.

Because southern states failed to provide suffrage for blacks, Congress saw the need to declare martial law to keep the peace and protect former slaves. In 1867 the U.S. Congress had passed The Second Reconstruction Act, which was both fueled and limited by issues of race and disenfranchisement. The Second Reconstruction Act required voters to recite an oath pledging their support and obedience to the constitution, and it sanctioned a military presence in the South to register voters and arrange elections. ${ }^{52}$ North Carolina historian Jim Leloudis noted that North Carolina missed many opportunities to move beyond biased thinking and Jim Crow laws in order to progress to a more prosperous and healthy state. $^{53}$

In this environment of tense race relations and extreme poverty, blacks and poor whites faced significant obstacles to medical care. The limited supply of doctors, nurses, dentists, and hospitals in the remote rural regions of the South especially complicated the health needs of blacks. One physician addressed the issue of trust in the medical system when he wrote that the "sick man may not seek the 
doctor and he may be afraid of the hospital." 54 This very reason justified the need for black public health nurses who already had the trust of a community at highest risk for illness and death.

Because of race relations and mistrust of whites, blacks were often wary of seeking health care. In the South, there were a limited number of doctors and nurses per 1,000 people compared to the ratio of doctors to people in the urban areas. ${ }^{55}$ According to one report in 1929, sixteen percent of blacks who died did not seek medical care at all during the last six months prior to their death. In 1934, that number rose to 23 percent. ${ }^{56}$ Low income directly correlated with insufficient medical care for blacks and whites but was more pronounced in blacks. This issue of supply and demand was compounded by the fact that there were not only fewer nurses available, but also poor blacks were less likely to seek their services.

The Need for Health Care Initiatives by Blacks in the South

While some health officials used morbidity and mortality statistics as proof of 'racial degeneration,' some leaders in the black community were attempting to fight for the need for social reform for blacks in the South. ${ }^{57}$ While North Carolina Mutual Life Insurance Company reported higher rates of morbidity and mortality among blacks, white public health workers were simultaneously initiating widespread education measures to improve these statistics. These progressive public health workers sought to dispel the myth that differences in disease incidence were because of race, but rather were the result of correctable environmental conditions. ${ }^{58}$ Similarly, black health care leaders had to look beyond assumptions of genetic inferiority as reasons for illness in the black community and address issues of education, sanitation, and class as potential barriers to good health. ${ }^{59}$

In 1915, Tuskegee Institute, founded in 1881 by Booker T. Washington as a black educational institution, worked in cooperation with the U.S. Public Health Service, State Boards of Health, and the National Health Council to institute National Negro Health Week in an effort to improve the health of blacks through public health education. ${ }^{60}$ The program, started in 1915, provided a week of intensive focus on hygiene and suggestions to improve the actual health conditions. ${ }^{61}$ The effort involved various community organizations and educational institutions across the South widely distributing specially 
prepared health education materials to churches, lodges, schools, and colleges. ${ }^{62}$ The specific health and education needs of blacks during this era were addressed by such groups as the National Association of Colored Graduate Nurses and workers of the National Negro Health Movement. Much work was done to understand and alleviate the barriers to health care that impacted blacks in the rural South, including increasing the black nurse workforce to provide blacks communities more access to care. ${ }^{63}$

In addition to these initiatives, local businesses also played an important role in public health reform. A coalition with large insurance companies provided public health education for blacks in the South. The Metropolitan Life Insurance Company, the black-owned North Carolina Mutual Life, and various other insurance companies positively affected a significant portion of members of the black community who would have otherwise been overlooked by existing public health efforts. Companies provided blacks with written materials that educated them on basic matters of disease prevention such as hygiene. In addition, the insurance companies offered periodic physical examinations and nursing services, thereby extending the reach and impact of public health reform to a population desperately in need of care. ${ }^{64}$

North Carolina Mutual Life Insurance Company, based in Durham, North Carolina, for example, was one of the black owned and administered businesses in the South. In 1925, the black owner found it profitable to provide initiatives to keep his clients well. ${ }^{65}$ The company hired medical providers, mostly physicians, conducted field visits, taught classes, showed educational films, and distributed bulletins. North Carolina Mutual Life Insurance Company hired a black physician for its Life Extension Department and turned part of its headquarters into a virtual hospital. In addition, the insurance company offered periodic physical examinations and nursing services thereby extending the reach and impact of public health reform to a population desperately in need of care. ${ }^{66}$ As a result of these public health initiatives on the part of North Carolina Mutual, there was a notable decline in overall mortality of blacks. ${ }^{67}$ 
In 1921, the U.S. Congress passed the Sheppard-Towner Act (The Promotion of the Welfare and Hygiene of Maternity and Infancy Act). Sheppard-Towner funding significantly increased the amount of nursing care provided to women and children in rural North Carolina. The federal government appropriated $\$ 1,240,000$ for health promotion for women and children, which funded prenatal clinics, public health nurse prenatal and postnatal visits to women, wellbaby visits, and midwife training. ${ }^{68}$ In 1922, North Carolina reorganized the Bureau of Public Health and Infant Hygiene into the Bureau of Maternity and Infancy. Although SheppardTowner was repealed in 1929, by then 94 nurses were employed by county health departments. While private agencies like the Rockefeller Foundation, the American Red Cross, and the Metropolitan Life Insurance Company played an important role in public health (Chapter 2), Sheppard Towner's federal funding was especially instrumental in the growth of public health nursing in North Carolina. ${ }^{69}$

New Deal Policies in the 1930s

In 1932 President Franklin Roosevelt promised a 'New Deal' for the American people that included a variety of federal relief programs intended to provide financial support as incentive to end the Great Depression. Roosevelt gave a strong message that it was the responsibility of the federal government to ensure a minimum quality of life for all citizens. ${ }^{70}$ Federal aid enhanced the development of new public health services that included health education programs for public health agencies, the development of local health departments, and reemployment of a vast number of nurses into the field of public health. The Federal Emergency Relief Act (FERA) was passed in 1933, followed by the Civil Works Administration (CWA) and Work Progress Administration (WPA). All significantly affected the delivery of health care to needy families. The FERA was the first relief program established by Roosevelt that provided financial assistance to the unemployed. ${ }^{71}$ The CWA, established in 1933 to repair highways 
and roads initially, was expanded to include bridges, schools, hospitals, and playgrounds, and employed almost 4 million Americans. ${ }^{72}$ The WPA was a work relief program employing 8.5 million Americans building bridges, roads, airports, public buildings, and parks. ${ }^{73}$

During Roosevelt's administration, some conditions would change for southern blacks. The Social Security Act of 1935 provided financial stimulus for the reorganization of public health departments in rural areas, providing some access to health care for rural blacks. According to Davis, "For the rural Negro, the establishment of well-organized local health departments is the first step towards providing the elements of modern medicine." 74 The Social Security Act also supported public health nursing in providing funding for care of crippled children, maternal/child welfare programs, maintenance of local health departments, and additional public health research and training for public health nurses. ${ }^{75}$ The Act ensured unemployment insurance, pension plans, and help for the blind and destitute children of America. ${ }^{76}$ It also provided matching funds to states for maternal and infant care, rehabilitation of crippled children, and general public health work. Clearly, federal funds and public health work coalitions were a necessity in improving the health of rural southern blacks. The state health departments simply did not have the resources to do so.

The FERA was one of many programs that had a direct effect on nursing, especially in the field of public health. In 1933, the North Carolina Emergency Relief Act (NCERA) began operation after the state received $\$ 2,739,010$ of FERA funding. The NCERA public health projects provided employment for 216 registered nurses who focused on health promotion and disease prevention by giving general health education talks, training lay midwives in sanitary techniques, and providing home health nursing among many other public health services. ${ }^{77}$

In June of 1933, FERA provided funds for medical, nursing, and dental care. The CWA provided rural sanitation to control the hookworm epidemic that was spreading because of improper or inadequate disposal of sewage. The WPA and Public Works Administration built hospitals, sewer plants, and other major projects to improve the health of the public. All of these agencies, along with Social Security legislation, caused a surge in use of and availability of home health nurse visits for maternal-newborn 
care, education, and health promotion. ${ }^{78}$ Black nurses took advantage of these measures to enhance their employment prospects and work to improve the health of the local black population.

\section{Public Health Reform}

The New Deal proposed by Roosevelt had the potential to radically change the way blacks received health care. The New Deal shifted control of public health programs from local government to national agencies like the United States Public Health Service, American Red Cross, large insurance companies, and the Office of Negro Health Work. ${ }^{79}$ As well, the U.S. Public Health Service was in a better position to extend services to blacks who were not previously recipients of adequate health care. The attempts made by federal agencies gave community organizations a platform to collaborate and form alliances with medical and nursing professionals. Local businesses, like the North Carolina Mutual Life Insurance Company, were known to appoint an employee to serve as community liaison and translator, helping blacks understand and accept the new federal assistance, but it is unclear how many of these employees were nurses. One example of federal involvement was the Office of Negro Health Work (a division of the USPHS), which became the headquarters for the National Negro Health Week campaign. ${ }^{80}$

\section{Public Health Challenges in North Carolina}

Yet nurses faced huge challenges. Historian Edward Beardsley concluded that poverty in the South created an attitude of fatalism and pessimism that was as much a barrier as practical aspects like rurality and lack of transportation. Attitudes like denial of illness, reluctance to follow medical advice, and resorting to a lay referral system of getting second opinions from family and friends were all obstacles that public health nurses had to address when visiting sick families. ${ }^{81}$ Travel to doctors' offices was infrequent due to lack of transportation and average distances of eight miles. While vaccinations 
were available to black tenant families, only four percent were vaccinated for smallpox and less than one percent for typhoid. ${ }^{82}$

The public health challenges in North Carolina were similar to trends across the United States. Tuberculosis mortality statistics in North Carolina were similar to those across the nation. ${ }^{83}$ One rural county on the Virginia and North Carolina border reported the following vital statistics for the period of 1921-1930 for white and black populations:

Gross mortality, 11.2 per 1,000 population; measles, 7.2; typhoid fever, 11.0; pellagra, 11.6; diphtheria, 12.5; whooping cough, 16.7; diarrhea and enteritis among children under 2 years of age, 41.0; infant mortality, 71.4 ; tuberculosis, $106.0 .^{84}$

Yet mortality rates for blacks were consistently higher than for the white portion of the population. ${ }^{85}$

In 1920, maternity illness and death was the third leading killer with 41.3 per 100,000 in blacks compared to 27 per 100,000 in whites. In the 1920s and 1930s, syphilis and gonorrhea were especially

prevalent in the black community. ${ }^{86}$ By 1930 in North Carolina, heart disease had surpassed tuberculosis

in mortality rates. ${ }^{87}$ Vital statistics at the beginning of 1930 showed no change in tuberculosis death rates, a decrease in typhoid fever, measles and diphtheria, an increase in influenza and pneumonia deaths due to a recent influenza epidemic, and an increase in death from chronic diseases such as organic heart disease, cancer, and diabetes ${ }^{88}$ The vital statistics reported for the decade prior to the Depression reflected a public health need for education on cleanliness and prevention of the spread of infection; both of which were objectives of the public health nurse in the South.

\section{Public Health Nursing Overview}

The early years of the $20^{\text {th }}$ century saw significant growth in the field of public health nursing. Prior to 1912, when the Red Cross established its first public health nursing division, the Town and Country Nursing Service, visiting nursing services were primarily available to urban dwellers. After 
1912, the Town and Country Nursing Service offered neighborhood health services to the rural poor. In the 1930s, the program was supplementing the care of country practitioners whose demand far exceeded supply in the rural areas. The Red Cross' mission was to first recruit and train rural nurses, encourage districts to take on the new responsibilities, then move on to a new community in need of such services. ${ }^{89}$

The initiative of the Henry Street Settlement and Metropolitan Life Insurance Company in large cities like New York and Boston impacted the field of public health nursing. These initiatives showed the value of visiting nurse services in improving the health of the public, and subsequently enhanced public health delivery throughout the rural South. From 1924 to 1931, there was a 33 percent increase in public health agencies, and a 42 percent increase in the number of public health nurses. ${ }^{90}$ The majority of public health nurses were employed by local agencies subject to the availability of local funding. National economic crises, like the stock market crash of 1929 and the subsequent economic depression, had a direct effect on the ability of local agencies to employ nurses in the field throughout the rural South. In 1931 only one-fourth of the counties in North Carolina had a public health nurse. A similar trend could be found in many other southern states. ${ }^{91}$ While statistics reflected a decline in the overall death rate, the far-reaching effects of poverty on the health and well-being of the poor rural farmers manifested itself through increases in nutrition related diseases like pellagra. ${ }^{92}$ North Carolina, in 1931, employed 165 public health nurses but only 20 were black nurses. ${ }^{93}$

In the rural South in the 1930s, public health nurses were particularly important in providing care, and were influenced considerably by the Metropolitan Life Insurance Company due largely to a partnership established in 1909 by Lillian Wald, Director of the Henry Street Settlement, to improve the health of industrial workers and low wage earners. ${ }^{94}$ Metropolitan Life established a Metropolitan Nursing Advisory Committee in 1934, which joined the services of visiting nurses, boards of directors, leaders of professional nurse associations, and public health professionals to improve the quantity and quality of public health nursing. What made Metropolitan Life Insurance Company's contribution unique was that, while other companies provided care for their employees, Metropolitan Life expanded nurse 
services to all its policy holders, thereby providing care to some 7,394 communities across the United States. ${ }^{95}$ Twelve percent of their policy holders were black, as a result more than one million blacks across the nation became entitled to home nursing care. Business contracts like this put companies like Metropolitan in a prime position to enhance local and national public health practice without the patriarchal tone of some government public health policies of the time. ${ }^{96}$

\section{Black Nurses' Professional Challenges}

Since the first slaves arrived in the United States in the seventeenth century, black women were involved in the fight to improve the health of blacks through education and nursing care. However black nurses fought multiple battles in their evolution in the early 1900s. Many were drawn to nursing out of a need to serve their community. However this battle could not be fought without simultaneously addressing the struggles of black women in a time of racial and gender discrimination. The same circumstances that negatively affected blacks in the 1920s and 1930s, racism and disenfranchisement, limited black nurses' ability to positively impact the health of their communities. ${ }^{97}$

Franklin O. Nichols, from the Department of Education Measures, was a black social worker hired to direct social hygiene work in the black population. Nichols argued strongly for the benefit of better opportunities for black nurses in the South. He believed that improving the health of blacks was a necessity for the health of the entire population. This could be accomplished through adequate hospitalization, less discrimination in health services available to blacks, and more aggressive public health care by black doctors and nurses.

Black nurses were often assumed to have had inadequate training, however, and were often paid less. Yet in many states, black and white nurses took the same licensure examinations regardless of where they trained, so differences in salary could not truly be justified based on training. ${ }^{98}$ Black nurses did not have the same opportunities for specialty training in public health, though, because of the limited 
number of training facilities for public health in the South. Therefore, their opportunities for entry into the field of public health were limited. ${ }^{99}$

Despite these challenges, black nurses, serving as the translators, motivators, and mediators between patients and physicians, commanded respect in their communities. On the occasions where blacks were seen in doctor's offices, health information relayed during the all too brief and infrequent encounters with white physicians was often misunderstood by patients due to educational and cultural gaps. But the black nurse, who had established trust and respect within the community, was able to bridge these gaps. Black nurses were often the only source of health care to many blacks during this time. While white nurses were willing, in many cases, to provide care to the black community, cultural differences and issues of mistrust on the part of blacks remained a barrier to adequate nursing care of this vulnerable community. In short, black nurses were needed to meet the needs of black patients in the rural South. ${ }^{100}$

Conclusion

The Great Depression was a period of economic crisis in United States history but was particularly trying for those in the rural South who were poor and in desperate need of nursing care and health education. Americans' economic suffering during the Great Depression led the federal government to respond with support and funding to improve the general public health by aiding those who were most vulnerable. Federal legislation prompted the development of public health services: new programs for public health agencies, supportive services from federal agencies to develop local health departments, and reemployment of a vast number of nurses into the field of public health. Black nurses took advantage of these opportunities. As a result of increased federal funding, public health nurses organized professionally and standardized public health nursing care. Due to the health education delivered by New Deal nurses, 
the associations between sanitation, nutrition, and environment became more evident, and people came to understand how much they could improve their own health. ${ }^{101}$

Of particular significance, there remained a need for unique initiatives for the nation's most vulnerable groups: blacks living in poor physical, financial, and social conditions amidst a racially divided region. It was in this environment that black public health nurses worked to meet the needs of the black residents of North Carolina.

\footnotetext{
${ }^{22}$ Sir Michael Marmot, "Forward," in History of the Social Determinants of Health: Global Histories, Contemporary Debates, Harold J. Cook, Sanjoy Bhattacharya, and Anne Hardy, ed. (Hyderabad, India: Orient Black Swan Publishers, 2009), 14-16; and The Health Gap: The Challenge of an Unequal World (London: Bloomsbury Press, 2015).

${ }^{23}$ Dewey Grantham, Southern Progressivism: The Reconciliation of Progress and Tradition (The University of Tennessee Press, 1983).

${ }^{24}$ Howard Rabinowitz, The First New South: 1865-1920 (Virginia: Harlan Davidson Press, 1992).

${ }^{25}$ William Link, The Paradox of Southern Progressivism: 1880-1930 (Chapel Hill: The University of North Carolina Press, 1992).

${ }^{26}$ Michael Gray, New Deal Medicine: The Rural Health Programs of the Farm Security Administration (Baltimore: The John Hopkins University Press, 1999).

${ }^{27}$ Link, The Paradox of Southern Progressivism.

${ }^{28}$ Ibid.

${ }^{29}$ E.C. Branson, "Farm Tenancy in the Cotton Belt: How Farm Tenants Live," Social Forces 1, no. 3 (1923): 213.

${ }^{30}$ Carl Taylor and C. Zimmerman, "North Carolina Tenancy Commission (NCTC)", Economic and Social Conditions of North Carolina Farmers (Chapel Hill: North Carolina Collection, University of North Carolina, 1922), 6-7.

31 Taylor and Zimmerman, Economic and Social Conditions.

32 Taylor and Zimmerman, Economic and Social Conditions.

${ }^{33}$ Guy Johnson, "Race, Cultural Groups, Social Differentiation: The Negro and the Depression in North Carolina" Social Forces 12 (1933): 103-115.
} 
${ }^{34}$ Michael Davis, "Problems of Health Service for Negroes," The Journal of Negro Education 6 (1937): 438-449.

${ }^{35}$ Edward Beasley, A History of Neglect: Health Care for Blacks and Mill Workers in the TwentiethCentury South, (Knoxville: The University of Tennessee Press, 1987).

${ }^{36}$ Ibid.

${ }^{37}$ C.H. Atkins, "National Inventory of Needs for Sanitation Facilities: IV. Rural Sanitation," Public Health Reports (1944), 969-978.

${ }^{38}$ John Ettling, The Germ of Laziness: Rockefeller Philanthropy and Public Health in the New South, (Cambridge: Harvard University Press, 1981); C.H. Atkins. "National Inventory of Needs for Sanitation Facilities: IV. Rural Sanitation.” Public Health Reports.

${ }^{39}$ Johnson, "Race, Cultural Groups, Social Differentiation."

${ }^{40}$ Franklin O. Nichols, "Opportunities and Problems of Public Health Nursing Among Negroes," Public Health Nurse (1924): 121-123. It is not clear whether F.O. Nichols was white or black.

${ }^{41}$ William Link, North Carolina: Change and Tradition in a Southern State (Illinois: Harlan Davidson, Inc., 2009).

${ }^{42}$ Tom Hanchett, "The Rosenwald Schools and black education in North Carolina," The North Carolina Historical Review 65 (1988): 4.

${ }^{43}$ Robert Korstad and James Leloudis, "Citizen Soldiers: The North Carolina Volunteers and the War on Poverty," Law \& Contemporary Problems 177 (1999).

${ }^{44}$ Hanchett, "The Rosenwald Schools."

${ }^{45}$ C. Vann Woodward, The Strange Career of Jim Crow (New York: Oxford University Press, 1966).

${ }^{46}$ Davis, "Problems of Health Service."

${ }^{47}$ Megan Wolff, "The Myth of the Actuary: Life Insurance and Frederick L. Hoffman's Race Traits and Tendencies of the American Negro," Public Health Chronicles 121 (2006): 84-91.

${ }^{48}$ Nichols, "Opportunities and Problems."

${ }^{49}$ Jim Leloudis and Robert Korstad, To Right These Wrongs (Chapel Hill: University of North Carolina Press, 2010). In A History of Neglect: Healthcare for Blacks and Mill Workers in the $20^{\text {th }}$-Century South, Edward H. Beardsley (Chicago: University of Tennessee, 1990) argues that both blacks and whites were poor. Indeed poverty, not just race, was influential.

${ }^{50}$ Edward Beardsley, A History of Neglect: Healthcare for Blacks and Millworkers in the $20^{\text {th }}$ Century South (Chicago: University of Tennessee Press, 1990).

${ }^{51}$ W.E.B. Du Bois, The Souls of Black Folk: Essays and Sketches (Cambridge: University Press John Wilson and Son, 1903). 


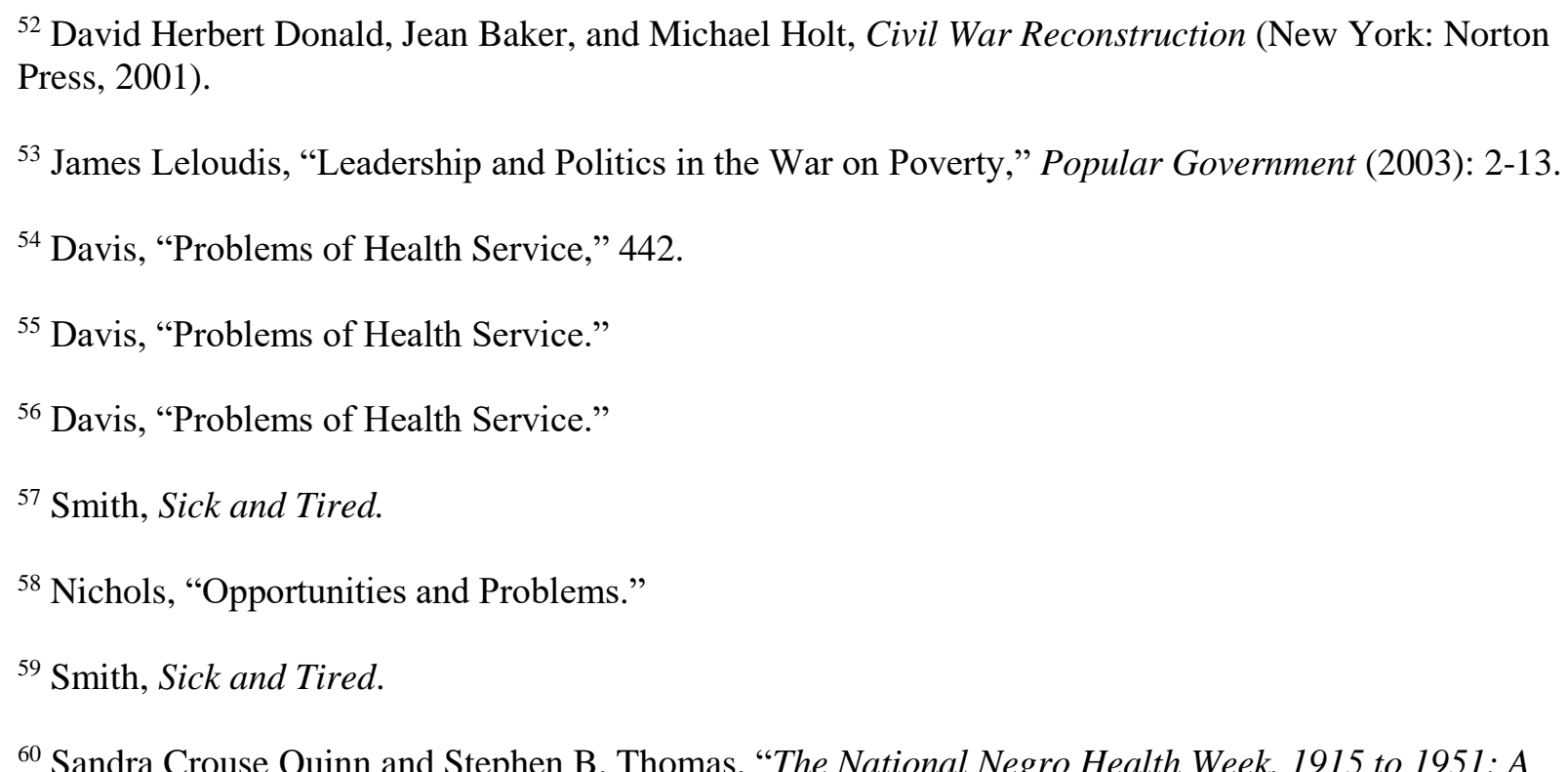
Descriptive Account," Minority Health Today 2 (2001): 44-49.

${ }^{61}$ Quinn and Thomas, The National Negro Health Week.

${ }^{62}$ Nichols, "Health Measures."

${ }^{63}$ Darlene Clark Hine, Black Women in White: Racial Conflict and Cooperation in the Nursing Profession, 1890-1950 (Bloomington \& Indianapolis: Indiana University Press, 1989).

${ }^{64}$ Walter Weare, Black Business in the New South: A Social History of the North Carolina Mutual Life Insurance Company (Chicago: University of Illinois Press, 1973).

${ }^{65}$ Virginia King and Kenneth Kiple, Another Dimension to the Black Diaspora (Cambridge: Cambridge University Press, 1981).

${ }^{66}$ Franklin O. Nichols, "Health Measures as They Relate to the Negro Race," Annals of the American Academy of Political and Social Science 140 (1937): 294-298.

${ }^{67}$ Weare, Black Business in the New South. Since NC Mutual Life Insurance was started by black physicians for the care of the black community, one would assume that they hired primarily black doctors and nurses for public health education. However, the exact numbers of black/white workers has been difficult to locate. Public health workers hired by the state were typically white male of varying educational background and experience.

${ }^{68}$ Pollitt, The History of Professional Nursing.

${ }^{69}$ Plyler, Public Health Nursing in North Carolina.

${ }^{70}$ Gray, New Deal Medicine.

${ }^{71}$ Edward Ainsworth Williams, Federal aid for relief (New York: Columbia University Press, 1939). 
${ }^{72}$ http://www.pbs.org/wgbh/americanexperience/features/general-article/dustbowl-wpa/

${ }^{73}$ http://www.pbs.org/wgbh/americanexperience/features/general-article/dustbowl-wpa/

${ }^{74}$ Davis, "Problems of Health Service," 445.

${ }^{75}$ Williams, Federal aid for relief.

${ }^{76}$ Pollitt, "Nursing and the New Deal: How we met the challenge," Public Health Nursing 14 (1997).

${ }^{77}$ Pollitt, "Nursing and the New Deal."

78 “Health \& the New Deal” (2001), http://www.encyclopedia.com/printable.aspx?id=G2:3468301287

79 "Health and the New Deal."

${ }^{80}$ Phoebe Pollitt, "Commentary: From National Negro Health Week to National Public Health Week," Journal of Community Health 21 (1996): 401-406.

${ }^{81}$ Beardsley, History of Neglect.

${ }^{82}$ Taylor and Zimmerman, Economic and Social Conditions.

${ }^{83}$ King and Kiple, Another Dimension to the Black Diaspora.

84 "Job Analysis of a Rural Health Officer: Brunswick-Greensville Health Administration Studies No. 6," Public Health Reports (1896-1970) 50 (Dec. 13, 1935): 1751-1762, quote p. 1752.

85 "Job Analysis of a Rural Health Officer."

${ }^{86}$ Ibid, 55.

${ }^{87}$ Beardsley, History of Neglect.

${ }^{88}$ Harry H. Moore, "Public Health and Medicine," The American Journal of Sociology 35 (1930): 982990.

${ }^{89}$ I. Malinde Havey, “Civilizing Rural Health” The American Journal of Nursing 37 (1937): 513-515.

${ }^{90}$ Census of Public Health Nursing, 1931.

${ }^{91}$ Census of Public Health Nursing, 1931.

${ }^{92}$ Guy Johnson, "Race, Cultural Groups, Social Differentiation.”

${ }^{93}$ Pollitt, "Nursing and the New Deal."

${ }^{94}$ Arlene Keeling, Nursing and the Privilege of Prescription (Ohio State University Press, 2007): Chapter 1. 
${ }^{95}$ Alma C. Haupt, "Thirty Years of Pioneering: In Public Health Nursing," The American Journal of Nursing 39 (1935): 619-626.

${ }^{96}$ Ibid, 3.

${ }^{97}$ Clark Hine, Black Women in White; M. Elizabeth Carnegie, The Path We Tread: Blacks in Nursing 1854-1990 (New York: National League for Nursing Press, 1991).

${ }^{98}$ Nanny Minor

${ }^{99}$ Nichols, “Opportunities and Problems of Public Health Nursing Among Negroes."

${ }^{100}$ Darlene Clark Hine, "They Shall Mount Up with Wings as Eagles: Historical Images of Black Nurses, 1890-1950," in Women and Health in America (Madison: University of Wisconsin Press, 1999), 475-488.

${ }^{101}$ Pollitt, "Nursing and the New Deal." 


\section{Chapter 3: Black Public Health Nursing Roles in North Carolina}

This chapter illuminates how white philanthropic foundations and black community leaders combined forces to improve access to adequate health care for blacks by improving access to nursing training for black women. By the mid-1920s, there were over 25 nursing programs for black women and close to 200 black hospitals in the United States, including Good Samaritan Hospital in Charlotte, St. Agnes Hospital in Raleigh, and Lincoln Hospital in Durham, North Carolina. ${ }^{102}$ This chapter focuses on case studies from two African American nurses from North Carolina: Edith McNeil Holmes who graduated from St. Agnes Hospital School of Nursing; and Elizabeth McMillan Thompson from Tarboro, North Carolina who graduated from Freedman's Hospital in Washington, D.C. ${ }^{103}$ The case studies show the convergence of classism, racism, and activism that affected their practice of nursing in rural North Carolina. Black public health nurses did it all: they worked in schools, trained lay midwives, operated clinics, taught classes, and worked in churches.

According to Ethel Johns, a white nurse known for her relatively unbiased evaluation of training programs for black nurses, black women faced a significant amount of racism in their roles as nurses that impacted their salary, work conditions, employment opportunities, and collaboration with their white counterparts. The Ethel Johns Report was published in 1925 through her work with the Rockefeller Foundation as a result of touring 23 black nursing training programs where she interviewed white nursing supervisors. Johns' summary of the relationship between black and white nurses was that "there was no sorority of consciousness across the color line." ${ }^{104}$ Black nurses throughout the South faced significant racial barriers from white doctors 
as well as their white nursing counterparts. As Judith Young argues, "Ultimately Johns assessed African American nurses as inferior and in need of supervision despite that, in her travels, she met some highly competent nurses doing excellent work."105 Indeed, "African American nurses...had to rely on their own meager resources to advance their cause."106

The challenge for black public health nurses in North Carolina was equally influenced by race, gender, and class. From the start of their nursing education as 18 year-old black women training in hospital nursing programs, they were treated as second class citizens. ${ }^{107}$ Yet they were not. They were part of an emerging black professional class of women as teachers and nurses. Indeed one vehicle to uplift black women to professional status was through the vehicle of nursing. Interestingly, their role as nursing students with inadequate pay and housing put them in a unique position to better relate to the poverty-stricken rural residents that they served. Student nurses at St. Agnes Hospital, housed in a private residence on the campus of St. Augustine College in Raleigh, worked in a house with no water except for the kitchen faucet, no hot water, no screens on windows or doors and "flying things innumerable," no plumbing, and inadequate food for patients, nurses, and staff. ${ }^{108}$ Their experiences surviving nursing training made them adaptive and innovative in meeting outcomes with limited resources.

Black Nurses and the Social Uplift Movement

Booker T. Washington stated that "The future of the race depends upon the conservation of its health."109 And W.E.B. Du Bois called for the "formation of local health leagues among colored people for the dissemination of better knowledge of sanitation and preventive medicine."110 According to Dr. Max King, a black physician and President of the Old North 
State Medical Society, "In light of the existing situation, an approach [is needed] through the process of education by members of Negro Organizations for improving social conditions. Social Service workers and others devoted to such causes are aiding much." 111 The Old North State Medical Society was the North Carolina affiliate of the National Medical Association, representing the interests of African American physicians practicing in the state caring for the black community. ${ }^{12}$ King also wrote, "It is quite evident that the most effective results must come by activities of those who sympathetically understand the psychology of those victimized by disease." ${ }^{\prime 13}$ It is with that conviction that the National Negro Health Week emerged in 1915 as a result of leadership in black education, medical and nursing associations, partnered with a strong lay public health movement. ${ }^{114}$

The role and daily functions of black nurses paralleled the lay public health movement spearheaded by black women throughout the nation. In the 1920s, black women were uniting to develop and implement self-help programs to promote education of black women for the uplift of the entire race. Black women formed women's clubs, and neighborhood unions focused on social service programs to improve the condition of homes, schools, and communities. Women's clubs gathered to teach necessary skills and trades such as cooking, sewing, carpentry, brick laying, and tailoring. Women formed coalitions to promote intellectual development of women by getting funding from within and outside of the community for new schools and public libraries. And neighborhood unions were formed that performed community health inspections and demanded better conditions from the city and state government agencies. Social research and investigations were prevalent in the black community, and they led to the development of programs to improve the black population's family standards, health status, and moral codes. ${ }^{115}$ 
Because social work and similar efforts towards social reform were slow to grow among the white population in the South, there was very little in place in the formal public health system to support black families in North Carolina. ${ }^{116}$ Therefore, concerned groups found less formal alliances like that between the State Association of Negro Registered Nurses (SANRN) and volunteers from black women's self-help initiatives. The SANRN held meetings in local churches that were open to members of the community. The women's groups that supported SANRN participated by helping bring families to well-baby and vaccination clinics. ${ }^{117}$

The South did have a social movement of its own that was created from the viewpoint that black health education was the conscientious duty of all leading citizens. National Negro Health Week, observed by blacks in North Carolina as well as other southern states, was organized by the Old North State Medical, Dental, and Pharmaceutical Society. It was also endorsed by the State Board of Health that wrote that the "safety of the people of North Carolina is only obtained by creating health consciousness in all citizens of the state." ${ }^{\prime 18}$ So while nurses and lay midwives primarily worked to address the more acute health needs of blacks, the lay health movement addressed the need for health education and promotion. And while the lay health movement was significant, black nurses training lay midwives was part of the larger public health movement.

The black nurse in the South had the complex mission of correcting superstitious and sometimes detrimental practices, educating poor families on preventive care, and delivering continuous health education to the masses in the midst of her own struggles with educational, professional, and racial barriers. Ethel Johns' statement speaks to the complicated dynamics of a black nurse working in the public health field: 
It is quite apparent that the "Negro" nurse cannot be utilized successfully in public health work except among her own people. Even among them she has not the same authority as the white nurse although she has a better psychological approach. She has been very successful in overcoming their superstitious fears regarding immunization, vaccination and other preventative measures. The social and economic problems involved in case work are commonly too much for her but she can ferret out information and interpret domestic complications which would baffle a white nurse who lacks her intuitive understanding of racial characteristics. ${ }^{19}$

Caring for impoverished patients had its unique challenges. Malnutrition was both a cause for disease and a barrier to seeking care for treatable conditions. When basic needs were not met (food, clothing, shelter, security), then preventive health care like immunizations became a lower priority. Impoverished patients often turned to folk practices, relying on the ancestral traditions and resources already available to them in their homes. Black women, trained as nurses or taking the role of lay midwife or community organizer, were tasked with the responsibility of health education in the black community.

Black lay midwives were both prevalent and necessary in the rural South where there were a limited number of physicians available to travel to rural areas for deliveries. These women were trusted women in the community who sometimes reported a spiritual calling to be in this line of work often despite inability to receive reimbursement from families for their work. These women travelled long distances, often under less than ideal travel conditions, to provide care for families in need. Lower income families relied on midwife services because it was more practical: it was cheaper than medical care; unlike doctors the midwives did not demand payment for services up front; and they offered value in providing additional homemaking services during the birthing period. ${ }^{120}$

Lay midwives were closely tied to the community because they lived amongst the community. Their practice included prayer, massage, and herbal remedies derived from African 
and European folk practices, which served the primary purpose of physical relief and emotional support. In spite of their passive role in the actual birthing process, they were seen by medical and public health officials as a "necessary evil." Public health officials were exasperated by their use of folk practices, the medical community was frustrated with their lack of initiative in seeking emergency treatment, and public health nurses were challenged in their attempts to modernize their practices. ${ }^{121}$ However, among rural blacks lay midwives were trusted health care providers and easily accessible to the members of the community with established relationships with clergy, schoolteachers, and business owners.

Often when poor families needed someone to care for their sick family members, lay midwives had an established track record of providing good care and education in their community. Logistically speaking, midwives were also often the most accessible person to provide any type of care. According to the annual report of the North Carolina State Board of Health in 1922, midwives delivered more than 30 percent of babies in North Carolina, and there were more than 5,000 midwives in active practice. ${ }^{122}$

Nursing care and health education focused primarily on the health of women and children since mortality rates were considerably higher in the black communities. ${ }^{123}$ Whites, however, were not the only ones to blame blacks for their conditions. According to Dr. Max King, a black doctor, "Ignorance and its ally—superstition—will cover so many of them [causes of death]."124 While this quote primarily viewed the victim as culpable, research at that time showed that these deaths were mostly influenced by factors such as environment, lack of care, and incidental diseases. It was the social conditions of poverty and social stresses that primarily contributed to disease and high mortality rates. 
Social Condition of Blacks in North Carolina

When evaluating the health of blacks in rural eastern North Carolina, it is important to first examine the home life and how it helped or hindered a foundation for good health. The family is the oldest known institution, and lays the foundation for shaping an individual's character. The black family's home life was challenged due to substandard housing which prompted Louis Dublin, a white statistician with Metropolitan Life Insurance Company, to note that blacks in urban and rural eastern North Carolina lived in "dreary dwellings, in neglected streets and rundown neighborhoods," in the least desirable section of cities and the poorest land in the rural counties. ${ }^{125}$ This was another case of blaming the victim for the problem of poor housing that led to poor health. However, Cynthia Neverdon-Morton complicates this quote. As a black historian, she described the home life of blacks in the early twentieth century. "The nucleus of the black population in southern cities," she wrote, "remained in the alleys behind the white residential areas...muddy and unpaved...centers of disease, extreme poverty, and social unrest." 126 Writers of both races spoke to the unfavorable environmental conditions that had a significant impact on the health of blacks.

\section{Midwife Supervision}

Gertrude Fraser has described the work of African American midwives in the South, and how they were gradually excluded from reproductive health care. ${ }^{127}$ Despite serious physician opposition however, midwives were necessary to meet the demands of a mostly rural North Carolina. Still one North Carolina physician wrote in the Southern Medical Journal that elimination of midwives was crucial because black lay midwives were "far below the European 
midwife in intelligence and no training under the sun could make her a competent obstetric attendant." ${ }^{128}$ In 1925, North Carolina led the nation in the number of lay midwives. The 6,500 midwives in the state delivered one-third of all babies, 20 percent of the white births and 80 percent of the black births. ${ }^{129}$ However, the lack of medical services and the large rural black populations prevented any drastic elimination of black midwives for years to come.

Audrey Umphlett, a white nurse who practiced in Northampton, supervised 20 lay midwives on deliveries day or night under what were often primitive conditions. What she discovered during her supervision was that some infants were contracting tetanus due to use of cobwebs by midwives for coagulation purposes. ${ }^{130}$ Umphlett's discovery was just one example of how some untested folk practices were indeed causing harm, and they supported the public health nurses' mission to modernize the care given by lay midwives.

By World War I, North Carolina was recognized nationally as "pacing the South" with health initiatives in sanitation, immunizations, and health education. Nursing leadership indeed had influenced the advances in public health nursing in the state. Rose Ehrenfeld was a white nurse and the first director of the Bureau of Public health Nursing and Infant Hygiene. She encouraged counties to secure funds for a nurse's salary and transportation, calling the nurse the "missing link between the health department and the home." Ehrenfeld's department reorganized into the Bureau of Maternity and Infancy in 1922 when the state of North Carolina matched over $\$ 27,000$ of Sheppard-Towner funds. ${ }^{131}$ After the war, rural health care was expanded as a result of draft figures showing that rural men were not as healthy, and Children's Bureau statistics showing that rural infant mortality rates and physical defects were higher in blacks and whites across the state. ${ }^{132}$ 
Government Funding for North Carolina

The stock market crash of 1929 led to massive unemployment of nurses in the workforce. Unemployment rose from four million in 1930 to 12 million in $1932 .{ }^{133}$ The American Red Cross reduced its nursing workforce from 3,000 in the 1920 s to 650 nurses in $1930 .{ }^{134}$ At the 1933 conference of the Southern Division of the American Nurses Association, Mary Roberts noted, "We have the social and economic paradox of the unemployed nurse and the unnursed patient which is no more paradoxical than the farmer with unsold wheat and children in the city begging for bread." ${ }^{\prime 35}$ This significant reduction in the nursing workforce affected all rural residents of Eastern North Carolina regardless of race.

\section{Public Health Nursing in North Carolina}

In North Carolina, private organizations like the Community Chest and the American Red Cross also funded public health. ${ }^{136}$ Public health nurses provided overall health screening, and they delivered community education about proper sanitation and nutrition counseling. They set up quarantines and held immunization clinics, ${ }^{137}$ although it is unknown whether black nurses participated in these quarantines in the black communities. The American Red Cross's nationwide initiative to establish rural nursing care led to the supervision of nurses in 50 to 100 North Carolina counties. The Red Cross nurses provided the only health care that many rural residents received during this period, as there was a shortage of physician manpower. ${ }^{138}$

Public health nurses played a key role as liaison between doctors, midwives, and the public. They translated information given by doctors during visits. They followed up in the home to ensure that the doctor's orders were properly implemented by the families. And they 
spread vital information and recommendations from the health department regarding sanitation and infectious disease precautions.

In 1931, however, only one fourth of the counties in North Carolina had a public health nurse in nearly every county (compared to bordering states like Virginia with one half of all counties with a public health nurse). The total number of public health nurses in the United States at that time was 15,053 . North Carolina employed 165, while other southern states like Mississippi employed only 35. The number of black public health nurses, however, was only 20 in North Carolina (similarly there was only one in Mississippi). ${ }^{139}$

While federal funding significantly increased the number of North Carolina public health nurses in the 1930s, only 15.7 percent of the total were black. This difference is important to address because of a common sentiment that the communication gap was worse when doctors or nurses were of a different race than their patients. Dr. Robert Moton, Principal and President of Tuskegee Institute wrote: "In the old days, southern whites told Negros what they thought Negros could understand and Negros told whites what they thought it was safe for them to know."140

In addressing the challenges of illness in the black community, Max King, President of the Old North State Medical Society, wrote, "One of the main services a democratic government must offer its citizens is a safeguard against ill health as well as security against other social evils. In North Carolina we have a population of about three and one half million people, about one million of whom are Negroes." ${ }^{141}$ He went on to write:

The task of making the people more health-minded is often retarded by the lack of adequate personnel to inculcate the philosophy of health. The generally poor educational advancement for its reception, together with occasional misguided direction of our weapons are hard in the rural areas, may make the results so discouragingly slow, that 
interest lags, and alertness gives way to indifference. I am convinced that social agencies of the Negro race could be more effective in aiding the State Board of Health in its vast program if more emphasis was placed upon the importance of periodically stressing the importance of health, even in the face of seeming indifference on the part of those whom we serve. ${ }^{142}$

According to the records kept by Metropolitan Life Insurance Company, the overall death rate of blacks across the nation was 62.5 percent higher than that of whites in 1925 . Across the top five critical diseases, blacks suffered at a rate two to eleven times higher than whites, even across gender and age subcategories. ${ }^{143}$ The Committee on the Cost of Medical Care Report stated that "blacks have health problems which are, on the whole, considerably more serious than those of whites. The Negro is America's principal marginal worker, and he suffers in the North as well as in the South from poorer housing, less adequate diet, less sanitary surroundings, more employment of married women and greater economic insecurity."144

The top six causes of death among blacks in 1926 were tuberculosis, organic heart disease, chronic nephritis, cerebral hemorrhage, pneumonia, and accidents. The overall death rate for blacks decreased from 17.5 per 1,000 to 14.0 per 1,000 due both to improvements in treatment of individual diseases like tuberculosis and to development of health activities in the South. ${ }^{145}$ One cannot attribute these statistics solely to good nursing care because of the simultaneous lay health movement by women that was improving health education.

These statistics also challenged the race inferiority theories held by some white leaders that blacks were sicker because they were the weaker race. Instead, the decreasing mortality trends reported by Dr. Dublin, Vice President of Metropolitan Life Insurance Company, supported the theories of environmental influence. Dublin questioned the racial makeup and adaptability of blacks in evaluating why mortality was higher in them, but he also considered 
environmental influence. He wrote in one summary of vital statistics, "I doubt whether we really know just what part of the higher mortality of the Negro is attributable to racial susceptibility and what part to the effects of racial customs and environmental conditions." ${ }^{146}$

\section{Elizabeth McMillan Thompson}

Although there were a few training schools for blacks in North Carolina, many black nurses were trained out of state, especially for public health. In North Carolina, there were no post graduate public health training programs for black nurses. Most black nurses completed specialized training in public health in northern states like Virginia and Maryland, if they received training at all. After training out of state, many were reluctant to return to the South for jobs with poorer pay and difficult working conditions. An exception was Elizabeth McMillan Thompson, the first black public health nurse in North Carolina. She left her home state of North Carolina to earn a bachelor's degree in nursing from Freedman's Hospital in 1929 in Washington, DC. She then completed a public health nursing degree in 1930 at Howard University. Thompson was reluctant to return to her home state of North Carolina but came back to work in Cumberland County because of a smallpox epidemic. ${ }^{147}$ When she returned to North Carolina, she worked in the public health field with field training from the physician who recruited her away from Washington, D.C.

While education and social activism were important factors in improving the progress of blacks, ${ }^{148}$ one cannot forget the impact of public health nurses' involvement. From the parallel advancement of public health and rural sanitation emerged the field of school nursing. The role of school nurse allowed nurses to establish trust with families through their care for the children, 
affording them the opportunity to get more involved in the home life of the family. Thompson stated, "...school nursing is quite important and gives the nurse a pretext to get into the home to learn about a child as a whole person and build on his family's strengths." ${ }^{449}$ While this may sound a bit deceptive, in reality getting into the homes and talking to patients individually was a means to get to know what specific needs the family had. Through the nurses' interactions with the child in the school, she was able to indirectly assess the health and social needs of an entire family. When nurses like Thompson were able to teach children hygiene practices, they were able to pass that information on to their parents who, she stated, "may have no money to endow their children, but you can teach them to give them clean clothes, full bellies, and love."150 Clearly Thompson instilled the value of cleanliness into the families and children that was so prevalent in the public health movement of the 1920s and 1930s.

Nurse Thompson's experience with folk medicine in rural North Carolina often validated local practices. She found that herbal remedy use was quite often successful. Research from the University of North Carolina showed that some of the roots and herbs actually had curative value. $^{151}$ There was a distinction, though, between local use of herbs and the superstition based practices of root doctors. In her oral history, Thompson recalled having fierce competition from root doctors who once threatened her to stay out of their territory. On one occasion, Dr. Foster, a local physician, and his nurse had to save a patient that was left to die by the root worker. They travelled to this patient's home for several weeks in a row administering antibiotic injections to save the patient. This incident caused many of the local residents to lose faith in the root doctor and built trust in the public health nurses and doctors. ${ }^{152}$

Public health nurses were licensed and trained registered nurses working in the community, and they travelled distances to deliver care to people who couldn't make the journey 
themselves. Because of isolation of rural eastern North Carolina families in counties like Halifax County, the public health nurse faced unique challenges to caring for her patients. During later interviews, nurses often discussed how difficult it was for members of the community to travel long distances to see their doctors, and how necessary it was for nurses to be able to travel to the homes of those families that were ill. Thompson practiced in eastern North Carolina in the 1930s, and she stated, "Unless we have nurses who have the people at heart and are willing to make sacrifices to help them obtain positive goals, we are still going to have poverty, pollution, and unsanitary conditions existing in our communities."153

Rural southern nurses faced unique challenges compared to their urban and Northern counterparts. Nurses in North Carolina gave more "medically oriented" care than nurses in New York because of the difference in physician manpower. In the North, nurses were able to do more referrals and follow up care; but in the South, nurses were busy staffing clinics and managing crisis situations with fewer supplies and resources. ${ }^{154}$

Between 1924 and 1931, there was a 33 percent increase in public health nursing agencies, and a 42 percent increase in number of nurses employed across the nation. ${ }^{155}$ More than 90 percent of public health nurses were employed by local agencies primarily due to Sheppard-Towner funding that employed many nurses. As well, with increased New Deal funding, local agencies were able to employ more nurses and therefore deliver more services to people living in remote areas. One North Carolina physician was quoted as saying: "Public health nurses are the ones that have made the changes that have come about in the health of the people...all these discoveries are great, but they don't do anybody any good if people don't know about them, or if they aren't motivated to accept them." 156 
Dr. Isa Grant, a white North Carolina physician who trained in the 1930s, believed that the community accepted public health nurses because of the "one-to-one relationship she had with mothers and families" and because the community valued the teaching and counseling skills she provided. ${ }^{157}$ Jean Lassiter, former director of the Eastern Regional Office of the Division of Health Services, was a white nurse in North Carolina who wrote that public health nurses who practiced in the 1930 s were the "original risk takers" who often had to make critical decisions under less than the best circumstances. Lassiter also believed that the work of public health nurses in midwife supervision was likely the most important factor in lowering the state's infant mortality rate. ${ }^{158}$

As noted earlier, lay midwives were common at the time as an ever-present member of the community. Some of the families lacked transportation, lacked funds for medical care, or had lost trust in the medical system. These families often relied on someone in the community that they trusted with their personal problems. Sometimes that person was the clergy, the local schoolteacher, and often the local midwife. Her presence resulted in trust and open communication. One white physician in North Carolina, a Dr. Cooper, hired four public health nurses across the state to develop programs for the education and supervision of midwives. Because of scarcity of doctors available to do deliveries, some counties like Sampson County had as many as 60 midwives performing deliveries. ${ }^{159}$ Trained or not, lay midwives became the primary health care providers for many rural remote communities in North Carolina. They educated pregnant and new mothers about how to care for themselves and their new babies. They also advised and educated the rest of the family on their health concerns. 


\section{Rural Sanitation Challenges}

Rural sanitation workers aimed to improve the equipment and water supply quality by designing better wells and cisterns for use in the communities. With the help of the Rockefeller Sanitary Commission, there was a steadily increasing availability of sanitary excreta disposal facilities. The United States Public Health Service conducted surveys and led programs to treat and install 2.9 million sanitary privies in 38 states. ${ }^{160}$ Of the 507,370 rural homes in North Carolina, 84,969 still had no privy and 75,184 had no water supply within 50 feet compared to the bordering state of Virginia where 33,253 of 37,450 had no privy. ${ }^{161}$

In urban settings like Wilmington, North Carolina, sanitation concerns were less on privies and more focused on water supply, and progress in urban community sanitation was a result of an organized community effort. However, the responsibility of maintenance of water supply and waste disposal rested on the individual homeowner. Therefore rural sanitation efforts had to start with raising awareness and interest and the benefits of providing a safe water supply

and adequate sanitary facility. ${ }^{162}$ Sanitation education thus became an important role of public health nurses.

Elizabeth Thompson spoke in detail about the impact that sanitation laws had on nurses in North Carolina. County commissioners passed a law in the early 1930s requiring every family to have a privy because landlords had not been too cooperative with sanitation recommendations in the past. Privies were built and delivered by WPA workers across the state. Unfortunately, passage of laws and even delivery of supplies was not enough because rural residents remained reluctant to utilize the privies. Therefore, public health nurses like Thompson had to do on site education to encourage and demonstrate the proper use of this new equipment to their patients 
and members of the community. ${ }^{163}$ Thompson recalled one story of teaching families that she visited how to use their privy:

...we'd go back sometimes a month later and the privy hadn't been used at all. So we ended up by showing them how to sit on the seat, then you had to show them how to keep the snakes from going in and making homes, and how to keep the spiders out so the children wouldn't be bitten. All this had to be taught to each family, for they knew very little about proper hygiene and cleanliness. ${ }^{164}$

Public health nurses also had to deal with hookworm infections that were prevalent in rural black communities because of the direct relationship between poverty and inadequate sanitation. ${ }^{165}$ The three major factors that impacted hookworm disease in poor rural North Carolina counties were: inadequate sanitation, poor housing construction, and limited access to essential medicines. The climate, sandy soils, extreme poverty of eastern North Carolina were an ideal environment for growth of hookworms. ${ }^{166}$

Public health sanitation workers recognized that human feces deposits on soil because of lack of access to proper waste facilities like privies put residents of high risk of exposure through both hands and feet. Houses constructed with dirt floors contributed to this risk of contact with hookworm in the soil. And finally, poor families had limited access to anthelminthic drugs or routine screening/deworming. ${ }^{167}$

New Deal legislation allowed sanitarians to provide proper structures to keep human waste out of the soil. Government funds allowed construction and delivery of privies throughout the South. The landscape of the South was modernized and home construction was improved to include more protection for families. And the public health nursing workforce was increased to allow more screening and care for school children with hookworm. ${ }^{168}$ 
Thompson talked about the impact of hookworm on black children as a result of poor sanitation in the communities: "big bellies, little bitty jaws, people walking around talking about children being fat and eating too much.... and them eaten up with hookworms! We had children die from hookworm, proven by autopsy reports." ${ }^{\prime 169}$

\section{Edith Holmes}

In 1923, Edith Holmes was a black nurse who graduated from St. Agnes School of Nursing in Raleigh. She began work at Halifax County health department in 1924, a position originally funded by Sheppard-Towner funds. In 1925, after a brief study of midwifery with Dr. Helen Moore of the United States Public Health Service, she returned to Halifax County to train the 75 midwives across the county using Julius Rosenwald funds. ${ }^{170}$

Holmes' nursing training was unconventional, but typical of black public health nurses of the time. Holmes only completed two years of high school at St. Augustus, where she then transferred to St. Agnes School of Nursing. Holmes had no formal public health nursing training, and had only on-the-job training conducted by two physicians. Her career as a public health nurse consisted of immunization clinics that occurred at the work sites in the fields and tobacco barns. In her oral history she recalled her work in Scotland Neck:

Some of the people in Scotland Neck couldn't get free from their work in the fields to come to the clinics at the schoolhouses. I drive my car out to the edge of the field where they were working, holler for them and give them their immunizations right there. I set up the equipment in the front seat of my car. ${ }^{171}$ 
Holmes was one of few black public health nurses practicing in the 1930s who was responsible for midwife supervision. She held weekly classes for midwives and conducted onsite supervision during postpartum visits. She inspected the midwives' supply bags to ensure that their equipment bag was properly stocked. In one class, she recalls demonstrating the sterilization process by putting the wrapped delivery kit in the oven with a potato. She taught her class that when the potato was done baking, the instruments had been sterilized for an adequate amount of time. ${ }^{172}$ Public health nurses were as innovative in their teaching strategies as they were in practice. Holmes believed that good public health nurses had unique traits that made them truly effective in their communities. A good nurse must "above all be sincere and not so critical of how others lived." She must take an interest in what people did in their homes and communities and even worship with them at times. Her oral histories indicate that she also believed that families must be taught that their children can have a better life than they had. ${ }^{173}$

North Carolina's public health infrastructure relied not only on clinicians like Holmes but also on the function of other central members of the public health team. Health inspectors, primarily white men, came to the field from a variety of technical and professional backgrounds. Sixty-four percent of these workers held no degree, and 71 percent received no public health training; but 70 percent of the field reported some years of practical public health experience. Health inspectors received the task specific training related to their functions of inspection and enforcement of sanitary codes. However as sanitation needs advanced, health inspectors were also responsible for supervision over housing hygiene, control of milk and water supplies, as well as various other community hygiene factors. ${ }^{174}$

Because white men were the health inspector work force, their agencies lacked the diversity necessary to understand and relate to female and minority members of the community. 
And in rural southern states like North Carolina, where racial tension was high, it was difficult to establish necessary rapport between white health inspectors and black community members. These tensions had to be addressed as white health inspectors, like the predominantly white nursing workforce, tried to overcome the cultural barriers that impeded adequate care for blacks in North Carolina. It was black nurses like Holmes who bridged the gap between the primarily white public health workforce, both health inspectors and nurses, and the black communities they served. Home inspections by white health inspectors were intrusive, and black nurses could assure families of the necessity of cooperating with these inspections in order to have necessary improvements done by their landlords. According to Holmes, "Some of the outside privies were very inadequate. We would report the worst situations to the sanitarians, and then they will go talk to the white landowners. Some of them [landlords] just didn't care and the sanitarians had to come down pretty hard on them." 175

Conclusion

Louis Dublin, the statistician with Metropolitan Life Insurance Company, once said “An improvement in Negro health, to the point where it would compare favorably with that of the white race, would at one stroke wipe out many disabilities from which the race suffers, improve its economic status and stimulate its native abilities as would no other simple improvement." ${ }^{\prime 176}$ This quote speaks to the impact of a solid foundation of good health on the improvement of the black race. North Carolina faced geographical barriers to caring for rural blacks, racial barriers to providing care for blacks, and the pre-FERA nursing workforce challenges. 
Federal funding minimized the nursing workforce barriers through reemployment of hundreds of nurses in the 1930s. Many nurses were put back to work, improving the access that blacks to receiving education, immunizations, and safe deliveries. Where private funding had fallen short of providing adequate care to many in rural communities, federal funding filled a much-needed gap in health services and providers. Federal funding also indirectly addressed the racial barriers to care by reemploying and providing specialized education to black nurses. Many believed that an increased black nursing workforce was the solution to eliminating racial barriers and improving the health outcomes of blacks in rural North Carolina. While the number of black nurses employed was still a relatively small proportion of the entire nursing workforce, the nurses that were involved made strides in providing care to members of their community.

Although never enough, the black public health nurses' work improved access to health care for mothers and their families through the various clinics, classes, and visits provided throughout the eastern part of the state. Perhaps most significant was their training of black lay midwives. The care and education given in the black community helped to reduce infectious disease rates, decrease chronic disease mortality, and reduce maternal and infant mortality rates. Although it was not nursing care alone that improved outcomes for blacks, public health nurses were able to positively impact the health of this community.

\footnotetext{
${ }^{102}$ Darlene Clark Hine, Black Women in White: Racial Conflict and Cooperation in the Nursing Profession, 1890-1950 (Bloomington \& Indianapolis: Indiana University Press, 1989), 9; Phoebe Pollitt, The History of Professional Nursing in North Carolina: 1902-2002 (Durham: Carolina Academic Press, 2014).

${ }^{103}$ The oral histories in this dissertation were obtained by Jane Plyler in 1979 in North Carolina.

${ }^{104}$ Clark Hine, Black Women in White, 98; and Darlene Clark Hine, "The Ethel Johns Report: Black Women in the Nursing Profession, 1925," The Journal of Negro History (1982): 212-228.
} 
105 Judith Young, "Revisiting the Johns Report on African American Nurses " Nursing History Review 13 (2005): 88.

${ }^{106}$ Ibid, 94.

${ }^{107}$ Clark Hine, "The Ethel Johns Report."

${ }^{108}$ Mary Glenton, The Story of a Hospital (Hartford, CT: Church Missions Publishing Company, 1923), 19.

${ }^{109}$ United States Public Health Service, "The National Negro Health Movement," National Negro Health News 18 (1950): 2.

${ }^{110}$ W.E.B. Du Bois, The Health and Physique of the Negro American (Atlanta: The Atlanta University Press, 1906), 110.

${ }^{111}$ Max King, “The Negro Health Problem,” The Health Bulletin 54, no. 3 (1939): 10.

112 “About Old North State Medical Society” Old North State Medical Society, accessed October 19, 2015, http://www.theoldnorthstatemedicalsociety.com/about/.

${ }^{113}$ King, "The Negro Health Problem,” 10.

${ }^{114}$ Sandra Crouse Quinn and Stephen Thomas, “The National Negro Health Week, 1915-1951: A Descriptive Account," Minority Health Today 2 (2001): 44-49.

${ }^{115}$ Cynthia Neverdon-Morton, "Self-Help Programs as Educative Activities of Black Women in the South, 1895-1925: Focus on Four Key Areas," The Journal of Negro Education 51 (1982): 207-221; Eugene Jones, "Social Work Among Negroes," Annals of the American Academy of Political and Social Science: The American Negro 140 (1928): 287-293.

116 Jones, "Social Work."

${ }^{117}$ Patricia D'Antonio, American Nursing: A History of Knowledge, Authority, and the Meaning of Work (John Hopkins University Press, 2010).

${ }^{118}$ King, "The Negro Health Problem," 10.

${ }^{119}$ Clark Hine, Black Women in White, 101.

${ }^{120}$ Molly Ladd-Taylor, “'Grannies' and 'Spinsters': Midwife Education under the Sheppard-Towner Act,” Journal of Social History 22 (1988): 255-275.

${ }^{121}$ Ladd-Taylor, "Grannies and Spinsters"

${ }^{122}$ W.S. Rankin, "Annual Report of the North Carolina Board of Health," The North Carolina Health Bulletin 37, no. 5 (1922): 9.

${ }^{123}$ King, "The Negro Health Problem." 
${ }^{124}$ King, "The Negro Health Problem."

${ }^{125}$ Louis Dublin. "The Health of the Negro," Annals of the American Academy of Political \& Social Science: The American Negro 140 (Nov 1928): 77-85.

${ }^{126}$ Neverdon-Morton, “Self-Help Programs,” 207-221.

${ }^{127}$ Gertrude Jacinta Fraser, African American Midwifery in the South: Dialogues of Birth, Race, and Memory (Cambridge, MA: Harvard University Press, 1998).

${ }^{128}$ Ibid p. 68.

${ }^{129}$ Holly Matthews, "Killing the Medical Self-Help Tradition Among African Americans: The Case of Lay Midwifery in North Carolina, 1912-1983," in African Americans in the South: Issues of Race, Class, and Gender (Athens and London: The University of Georgia Press, 1992), 60-78.

${ }^{130}$ Jane Plyler, Masters thesis: Public Health Nursing in North Carolina: Oral Histories of Earlier Years. 1979.

${ }^{131}$ Phoebe Pollitt and Camille Reese, "Nursing and the New Deal: We Met the Challenge," Public Health Nursing 14 (1997): 375-32; Pollitt, The History of Professional Nursing in North Carolina.

${ }^{132}$ Plyler, Public Health Nursing in North Carolina.

${ }^{133}$ J. Davidson and M. Lytle, The United States, a History of the Republic (Englewood Cliffs: Prentice Hall, 1988).

${ }^{134}$ Karen Buhler-Wilkerson, "Guarded by standards and directed by strangers," Nursing History Review (1993): 139-154.

135 J. Kirk, W. Cutler, and T. Morse, North Carolina Emergency Relief Administration (Raleigh: Edwards and Broughton, 1935).

${ }^{136}$ Kirk et al, Emergency Relief in North Carolina.

${ }^{137}$ Plyler, Public Health Nursing in North Carolina.

${ }^{138}$ Plyler, Public Health Nursing in North Carolina.

1391930 Census reports.

${ }^{140}$ The Negro in the New South, 151.

${ }^{141}$ King, "The Negro Health Problem."

${ }^{142}$ King, "The Negro Health Problem," 11.

${ }^{143}$ Dublin, "The Health of the Negro," 79. 
${ }^{144}$ Edward Beardsley, A History of Neglect: Healthcare for Blacks and Millworkers in the $20^{\text {th }}$ Century South (Chicago: University of Tennessee Press, 1990).

${ }^{145}$ Dublin, "Health Education of the Negro".

${ }^{146}$ Dublin, "Health Education of the Negro," 275.

${ }^{147}$ Plyler, Public Health Nursing in North Carolina.

${ }^{148}$ William Link, The Paradox of Southern Progressivism: 1880-1930 (Chapel Hill: The University of North Carolina Press, 1992).

${ }^{149}$ Oral history of Elizabeth Thompson by Jane Plyler, September 29 \& 30, 1979; Fayetteville, North Carolina.

150 Thompson oral history.

${ }^{151}$ Ibid

${ }^{152}$ Plyler, Public Health Nursing in North Carolina.

153 Thompson oral history.

${ }^{154}$ Plyler, Public Health Nursing in North Carolina.

1551930 Census reports.

${ }^{156}$ Plyler, Public Health Nursing in North Carolina.

${ }^{157}$ Plyler, Public Health Nursing in North Carolina.

${ }^{158}$ Plyler, Public Health Nursing in North Carolina.

${ }^{159}$ Oral history with Anne Lamb by Jane Plyler, November 20 and December 8, 1979; Clinton, North Carolina.

${ }^{160}$ C.H. Atkins, "National Inventory of Needs for Sanitation Facilities: IV. Rural Sanitation," Public Health Reports (1944), 969-978.

${ }^{161}$ Atkins, "National Inventory of Needs."

${ }^{162}$ Atkins, "National Inventory of Needs."

163 Thompson oral history.

164 Thompson oral history.

${ }^{165}$ Peter Hotez, "Hookworm and Poverty,” Annals of New York Academy of Science (2008): 38-44.

${ }^{166}$ Hotez, "Hookworm and Poverty." 
${ }^{167}$ Ettling, Germ of Laziness.

${ }^{168}$ M. Humphries, Malaria, Poverty, Race, and Public Health in the United States (The John Hopkins University Press, 2001).

169 Thompson oral history.

${ }^{170}$ Plyler, Public Health Nursing in North Carolina.

${ }^{171}$ Holmes oral history.

${ }^{172}$ Holmes oral history.

${ }^{173}$ Holmes oral history 1979.

${ }^{174}$ Mayhew Derryberry and George Caswell, "Qualifications of Professional Public Health Personnel: IV. Sanitation Personnel," Public Health Reports (1896-1970) ) 56, no. 8 (1941): 311-327.

${ }^{175}$ Oral history of Edith Holmes by Jane Plyler, December 1979; Weldon, North Carolina.

${ }^{176}$ Dublin, "The Health of the Negro." 


\section{Chapter 4: White Public Health Nursing Roles in North Carolina}

This chapter focuses on how black and white nurses worked together in complementary roles in the 1930s, addressing the complex health and social needs of impoverished blacks in North Carolina. Black nurses worked primarily in the homes, work sites, and schools providing education and direct care to black families. White nurses, however, more often served the role of supervisor to black and white public health nurses and lay midwives, where they indirectly influenced a higher standard of care for black families through training and supervising the nurses that provided care in these communities. White nurses partnered with the health department in the role of public health education in the sanitation movement, coordinating and organizing health education programs. White nurses were not limited in where they could practice, and therefore had much further reach than black women who could only work in black schools and communities.

White nurses facilitated key partnerships with health, welfare, and education officials to improve public health of all poor southerners, directly benefitting black families. North Carolina state government hired the first white public health nurse, Sadie Cabaniss, in 1916. Cabaniss had experience as a leader in the visiting nurse movement in Virginia, and eventually became the Director of Old Dominion School of Nursing. Cabaniss was hired in North Carolina through a combination of state and American Red Cross funds and eventually expanded her role to include maternal and infant care when Sheppard-Towner funds became available. ${ }^{177}$

As noted earlier, public health nurses in North Carolina were generalists responsible for nutrition programs, family casework, venereal disease control, supervision and training of lay midwives, mental hygiene, and tuberculosis nursing. They also worked in school health, 
although boundaries were blurred between school and community health. The first five registered nurses to work as school nurses in North Carolina were Birdie Dunn, Cleone Hobbs, Flora Ray, Cora Beam, and Katherine Livingston. ${ }^{178}$

North Carolina State Board of Health

A key collaboration for preventive health services was with the North Carolina State Board of Health. Dr. Thomas Wood of Wilmington led North Carolina to become the twelfth state to establish a state board of health in 1877 , with a chief responsibility "to inform the people of the state of matters pertaining to public health". The Board of Health went through four distinct periods of evolution. From 1877 to 1900, the focus was on print education, and the Board was responsible for "The Health Bulletin." The second period, from 1900 to 1920, centered on introducing health into the schools. The Board ensured physical examinations, adequate sanitary equipment, free dental clinics, hookworm surveys, infectious disease campaigns, travelling exhibits, motion pictures, and news conferences.

The third period, from 1920 to 1938, was credited for the establishment of a Bureau of Health Education, the Division of Oral Hygiene, and the School of Public Health at the University of North Carolina. Black nurses were not admitted to the University of North Carolina program, and indeed could not get special training in public health until 1938 at the North Carolina College for Negroes (now North Carolina Central University). ${ }^{179}$ Yet they were able to work in public health in various capacities. In the early $20^{\text {th }}$ century, the North Carolina State Board of Health organized the Bureau of Rural Sanitation with a mission to encourage local funding of public health work. One project of this bureau was the Medical Inspection of School Units that sent doctors and dentists to six counties across the state surveying thousands of 
children. As a result of the 1922 survey, they found that 80 percent of the school children needed dental treatment, more than ten percent had diseased throats, more than five percent had defective vision and/or hearing, and there were numerous other cases of tuberculosis, malaria, hookworm, and malnutrition. ${ }^{180}$ The findings led to publicity resulting in expanded work of the State Board of Health. Money became available by 1925 to hire six full time nurses to travel and provide screening and follow up at three-year intervals to school children up to seventh grade regardless of race. ${ }^{181}$ The final stage began in 1939 with a cooperative school health service that was a joint effort of the State Board of Health and the State Board of Public Instruction. ${ }^{182}$

Influence of Federal Funding on Collaboration in Public Health

While federal funding significantly increased the total number of public health nurses in North Carolina in the 1930s, as noted in Chapter 3, only a few were black. ${ }^{183}$ This disparity in the nursing workforce was a factor in the common sentiment that the communication gap between providers and patients was worse when doctors or nurses were of a different race than their patients. The disparity was also a reflection of the different nursing opportunities available to black and white nurses.

Until the black nursing workforce could be increased, white nurses were charged with finding a way to improve the reach and bearing of care given to all rural families, both black and white. One of the greatest challenges of the white public health nurse was her supervision and education of the lay midwife workforce. White physicians portrayed black lay midwives as ignorant and superstitious, "the typical, old, gin-fingering, guzzling midwife with her pockets full of forcing drops, her mouth full of snuff, her fingers full of dirt and her brains full of arrogance and superstition." 184 A white nurse working with this population, while perhaps 
subjected to those same sentiments, was not in a position to publically allow such feelings into her nursing perspective and practice. Unlike whites working in other professions, white nurses in Eastern North Carolina had to work with people in the community of all races and classes, and they had to build bridges and create new lines of communication for the sake of improving public health for all.

In the 1920s and 1930s, white male medical professionals were defining childbirth as a medical condition that required hospitalization. It was not to be left to immigrant or black midwives, but this was not possible in Eastern North Carolina and other areas of the rural South. ${ }^{185}$ Thus the ability of white nurses and black lay midwives to collaborate, establish trust, and facilitate communication was paramount, and it was evident in the rates at which lay midwives participated in trainings made available by state boards of health. Black lay midwives showed strength and determination as they continued to practice and grow in a time when they were held in great contempt. Meanwhile white nurses were exposed to new experiences of black culture that likely influenced their perspective and ability to connect with blacks in North Carolina. In an interview, Anne Lamb, a white public health nurse in North Carolina recalled her experience in the midwife meetings:

The meetings, which were held in the health departments, opened with prayer, then the midwives would usually sing awhile. I adored hearing them for they had beautiful voices. One time they were singing old timey religious songs and they got to clapping their hands, stomping their feet, and finally some were shouting. What we had to do was go up and put our arms around them and lead them out of the group, to sit quietly. It was hard to get much teaching done when they got to shouting. Eventually, they stopped doing this as they learned our expectations. ${ }^{186}$

With help from Sheppard-Towner funding, white nurses and black lay midwives created successful partnerships that allowed lay midwives to grow and improve their clinical skills. The 
White House Conference on Child Health and Protection held in 1932 found that "the Negro midwives have shown themselves eager and willing to avail themselves of such educational advantages as have been offered to them...by state boards of health." 187

The American Red Cross showed some success as well. For example, it employed 50 nurses in North Carolina between 1912 and 1935 to perform public health duties that included school health. ${ }^{188}$ Goldie Allen was one white nurse employed by the Red Cross who stressed the correlation between health and academic performance. She wrote, "Children with impaired vision, deaf ears, diseased tonsils, adenoids, undernourished bodies or fatigued nervous systems cannot do the work of normal children." "189 The Avery County Red Cross developed a "Progressive Program for Better Health" that rewarded schools for following eight health habits over a period of time. These included: 1) A full bath more than once a week; 2) Brushing teeth at least once a day; 3) Sleeping long hours with the windows open; 4) Drinking as much milk as possible (but not coffee or tea); 5) Eating green vegetables or fruit every day; 6) Drinking at least four glasses of water a day; 7) Playing a part of each day outdoors; and 8) A bowel movement every morning. ${ }^{190}$

\section{Public Health Challenges in North Carolina}

Amy Fisher completed her formal public health nursing training at William and Mary in 1928 and continued her education with a master's in public health funded by federal scholarship fund. Although she worked throughout the state, she spent most of her time as a nurse in the mountains of western North Carolina. Regarding her view on poverty and poor health among the patients she saw across the state compared to the residents in the mountains, she said "I really

don't think their problems were too much different from those of poor people anywhere else."191 
Fisher's nursing experience, much like the perspective of many public health spokesmen of the time, taught her that social class was a primary predisposing factor to poor health outcomes.

Yet another role for public health nurses was parish nursing. As a public health nurse, Fisher worked in Bible schools where she did home visits and health training for the children enrolled. She worked out of her home as a Parish Nurse for Missionary Society until the health department was started in Boone, North Carolina. And as a health department nurse, she participated in clinic days with the doctor providing venereal disease treatments, prenatal clinics, and typhoid and smallpox immunization clinics. ${ }^{192}$

Gender and Public Health

One public health discussion that North Carolina faced was the issue of power and control. In the birth control movement, poor women's rights, especially black women's rights, were infringed upon for the sake of the "greater good." Public health officials felt justified in making decisions that directly influenced a woman's choice to prevent a pregnancy based on the public sentiment that poor women were incapable of making these decisions for themselves. Women were denied contraception without written permission from their husbands. And when there was no husband, the woman had no legal voice of her own. ${ }^{193}$ Women threatened with sterilization, or tempted with financial help in exchange for agreeing to birth control, lost control of their reproductive autonomy to philanthropists, policy makers, and health and welfare professionals. As a result, many important decisions for women concerning their health were regulated without their input, allegedly in their best interest.

White nurses fit into a women's reform movement that occurred alongside black community activism and public health and sanitation reform. The contraceptive rights struggle 
was reflective of the public health discussion where similar assumptions made of poor black women regarding contraception, were made of poor black families when health policies were developed. Public health decisions made for, and not with, poor families were often deleteriously based on assumptions affected by race, gender, and class.

Charles McIver, president of the North Carolina Normal and Industrial College for Women at Greensboro, addressed more than 200 young white middle-class women urging their participation in revolutionizing the state through industrial transformation of North Carolina. McIver challenged the young women with organizing to improve the physical condition of the state's white public schools. As a result of his speech, the students founded the Women's Association for the Betterment of Public School Houses (WABPS) with a mission to eradicate illiteracy and poverty. WABPS gave white women a stronger presence to participate in public affairs and received wide recognition and support from local publications like the Raleigh News and Observer, the Biblical Recorder, and the Progressive Farmer. ${ }^{194}$

WABPS created new public roles for women as agents of social change, moving women from the home into the public using a woman-centered approach to community transformation. The women had a humanitarian approach using cleanliness and comfort to relieve "hard conditions of ignorance and illiteracy, weakness and poverty." ${ }^{195}$ While they may have professed to have a humanitarian mission, they still tried to instill white middle-class sensibilities. WABPS created a vision of uplift and development that was sympathetic to the poor but failed to address or impact the underlying issue of racial, class, and regional inequity. White nurses' approach was equally sympathetic to the poor but lacked the race and class sensitivities necessary for lasting change. 


\section{Race Collaborations to Address Environmental Factors}

Black leaders in the public health movement found that two powerful ways to regain power and control was for black leaders to create programs from within the black community and to encourage increased collaboration with white stakeholders. John Hunter, a black physician addressing the American Anti-Tuberculosis League, expressed an increasingly common sentiment of both blacks and whites on the need to "battle germs as their common enemy." Hunter's approach, much like that of Booker T. Washington, encouraged public health officials and his white physician counterparts to address the issues of class that obstructed health. Similar to other supporters of the sanitation movement, Hunter stated that "....for filth and bad whiskey beget disease and crime... whereas cleanliness begets health and godliness." ${ }^{196}$ His recommendations, albeit accommodating common beliefs about segregation, addressed the importance of a clean environment and the potential it had of uplifting the race.

Hunter's position was that environment outweighed any perceived differences in racial or genetic makeup, "Heredity does not balance the scale of environments, he wrote." His recommendations for prevention of infectious disease were similar in nature to public health interventions of the time:

Hold landlords accountable to make tenement houses more sanitary; doing away with one room shacks in the country; disinfection of houses where infection was present; compelling residents/tents to be more sanitary; teaching them proper sanitation methods; replacing cheap groceries and whiskey houses with free city bath houses. ${ }^{197}$ 
While black public health spokesmen directly blamed and addressed landlords, who they believed had the greatest influence on environmental living conditions for blacks, white nurses addressed residents of the community through health education in homes and schools.

\section{Race Collaboration on Education}

A mutual growth mindset was shared by Booker T. Washington and Julius Rosenwald as the impetus for changing education for black children. Rosenwald said "We whites of America must begin to realize that Booker T. Washington was right when he said it was impossible to hold a man in the gutter without staying there with him, because 'if you get up, he will get up.' We therefore must help the Negro to rise." 198

Washington's views of racial uplift were founded on the principal of blacks tolerating segregation and disenfranchisement while elevating themselves through hard work and material prosperity. W.E.B. Du Bois criticized Washington as too passive and even accommodating because he focused on racial self-help through education, agriculture, and economics, whereas Du Bois advocated for political rights. ${ }^{199}$ Likely because of his non-confrontational approach, however, Washington was successful at gaining the trust of influential white philanthropists like Rosenwald in order to implement programs to increase the number of schools and health programs for blacks in the South. Washington was able to convince white leaders that what was in the best interest of black children was also in the best interest of whites in the South.

As part of a countrywide movement to boost economic development through investment in human capital, a partnership formed that made profound changes in the education and health of blacks across the South. The Rosenwald Rural Schools Initiative was the result of a collaboration between Washington, principal of the Tuskegee Institute in Alabama, and 
Rosenwald, a successful Jewish businessman and philanthropist, who developed a matching grants program that created almost 5,000 schoolhouses across the South. The Rosenwald program made schools more accessible to rural blacks, and as a result these students completed a full additional year of school. ${ }^{200}$

In a 1922 Atlanta publication of The Constitution, Rosenwald was quoted as saying, "I am interested in the Negro people because I am also interested in the white people. Negroes are one-tenth of our population. If we promote better citizenship among the Negroes not only are they improved, but our entire citizenship is benefited."201 It was made very clear from the onset that this funding was intended to help both blacks and whites economically through better education of all American citizens in order to gain the support, or tolerance, of whites. Rosenwald funding offered support, rather than temporary aid, in a way that was not crippling to the black community. The funding was based on the premise of giving help only where help was wanted, where supported by local political structures, and where matching funds and help was available. ${ }^{202}$

Rosenwald's philanthropic interest in southern black schools created a new period of collaboration between black and white southerners. Rosenwald wanted to stimulate the public agencies to take a larger share of social responsibility and to spur a pattern of cooperation that would create a community initiative in cooperation between citizens and officials of both races. ${ }^{203}$ White nurses were able to capitalize on this new collaborative spirit to create better partnerships for health education in the black community.

New schoolhouses built through this community collaboration created new roles for both black and white nurses, and new opportunities for nurses, like the traveling Tonsillectomy and Adenoidectomy Clinic nurses, to influence the community. White nurses in North Carolina were 
hired as school nurses through both government and privately funded organizations to participate in programs such as the Catawba County Preventorium to provide medical care, proper nutrition, and health education to indigent children, and the Special Child Welfare Project where they examined 115,771 children and made home visits to 17,618 families in $1934 .{ }^{204}$

\section{Challenges With the School Environment}

The challenge in collaborating with the schools, however, was that they lacked the resources necessary to provide an adequate general education to rural communities in already poor health. The schools were charged with education that affected the entire family, and they were key resources in creating a thriving community. Among their many existing expectations was the need to provide health and sanitation education to the children throughout the state. The distribution of resources, unfortunately, was not equal between black and white schools, reflected by the increased morbidity and mortality of black families as a result of defective vision, defective hearing, diseased teeth, and afflictions of the nose and throat. One white professor in Atlanta noted that the school must share the responsibility for the continuous improvement of the social environment because it was the center of community life. ${ }^{205}$ The sentiment of this professor from Atlanta University was simultaneously insightful and critical. Dr. Winfred Nathan on the one hand agreed with Washington's statement at a National Negro Health Conference that, "The future of the race depends on the conservation of its health."206 Nathan stated that studies in health problems of blacks should incorporate social and geographic factors like poverty, poor housing, lack of medical services, prejudice, and ignorance. Echoing many of the white physicians' criticism, he also reported that the special health problems of 
black families, like tuberculosis, venereal diseases, and infant mortality could be traced back to poverty but also ignorance resulting in poor care by untrained midwives. ${ }^{207}$

\section{Educating Children in North Carolina}

The beginnings of establishing a sound educational system for blacks in North Carolina, in the early twentieth century, can be credited to Governor Aycock and State Superintendents Thomas Toon and J.Y. Joyner. The governor believed that for the state to progress, with an illiteracy rate of one in five overall and one in two for blacks, it had to be built on a strong foundation of adequate educational facilities for both whites and blacks. ${ }^{208}$ However, the current situation for blacks across the South was that they had limited school buildings, classrooms, and equipment. ${ }^{209}$

Through the 1930s in North Carolina, public elementary school education was usually seven grades plus four years of high school work. For the 1930 school year there were 2,339 black public elementary schools compared to 2,877 white schools throughout North Carolina. There were 63 black elementary schools with ten or more teachers, compared to 475 white schools with ten or more teachers. ${ }^{210}$ In the 1929-1930 school year, North Carolina was struggling with elementary school enrollment. In 1929, 54 percent of white school children were enrolled in first through third grades; by 1944, enrollment was down to 44 percent. For black school children, enrollment dropped from 66 percent in 1929 to 50 percent in $1944 .{ }^{211}$ Declining rates of elementary enrollment in the 1930s, as one African American writer noted, produced thousands of functional illiterate to hinder the state from its vision of a strong state. ${ }^{212}$ 
The North Carolina educational system had much higher student-teacher ratios in black schools and did not support Governor Aycock's vision of adequate facilities for both blacks and whites. In the 1929-1930 school year, while there were 243 accredited white schools, there were only eight accredited black schools. The teacher student ratios at the high school level were also unequal. Each white teacher would need to teach 59 children, where each black teacher would need to teach 215 children. ${ }^{213}$ For nursing, the issue of illiteracy and poor educational foundations posed significant barriers in their public health education efforts for both black and white North Carolinians.

One understated barrier to both public health and education was transportation. The success of the public health movement relied on reaching more children in the schools, however, the lack of school transportation was a significant barrier to improvement of both education and health. The state of North Carolina relied on transportation to get rural children to schools more heavily than any other southern state. Initial school bus purchases were made locally, but ultimately bus maintenance was the responsibility of the state. Small rural communities had to purchase buses using private funds or local fundraising, but this was not a feasible solution for every rural black community. ${ }^{214}$

The lack of transportation limited the state's educational development plans in the same way that transportation issues limited public health nurses' efforts to provide care to the masses. When school children could not get to the schools, this forced public health nurses further into the community to care for these families. Lack of transportation was a barrier that had to be overcome by both public health funding entities and the private fundraising efforts of black communities providing matching funds for Rosenwald schools and activities for the Black Health Movement. Transportation was yet another factor that slowed progress of public health 
reform, and in some cases affected support and morale. According to the black physician, Dr. Max King, "The generally poor educational advancement....may make the results so discouragingly slow, that interest lags, and alertness gives way to indifference.”215

Health Education Collaborations in the Schools

To ameliorate these problems, school health became a key area of collaboration between public health nurses and school officials in improving the health of the public, and it was where white nurses took the lead, as the first black nurse was not hired until $1938 .^{216}$ The state board of health, divided into nine divisions, included Preventive Medicine and Hygiene where white public health nurses were the driving force behind preventive health services. The nurse in this division conducted routine inspection of school children during the school year and classes for lay midwives in the summer months. These interactions were often the only exposure that rural school children had with either a doctor or nurse. ${ }^{217}$

State boards of health invested resources for nurses to work with school-aged children. The director of the Bureau of Rural Sanitation, Dr. George Cooper of Clinton, headed a program to eradicate infectious disease, improve rural sanitation, and coordinate medical inspection of elementary aged school children as early as 1917 . Cooper's programs, originally manned by physicians and residents, evolved to include follow up screening and treatment by nurses every three years for both black and white children across the state. The school health work included weights and measurements, vision and hearing testing, examination of oral cavities, and taking family and child immunization histories and disease history. ${ }^{218}$ 
In 1923, Anne Lamb, a white nurse, graduated from Cumberland General Hospital School of Nursing in Fayetteville, North Carolina, and continued her education with a certificate in maternity nursing. After a physician friend of the family convinced her to pursue public health nursing, she spent several years as a Tonsillectomy \& Adenoidectomy (T \& A) clinic nurse. Preoperatively, the nurses' role was traveling to schools in the winter, screening both black and white children for enlarged and infected tonsils. The nurses would refer children with problems to the local physicians, who would then refer them to the T \& A clinics. Lamb was part of a multidisciplinary team providing care in black and white schools across the state. The surgical team consisted of a doctor to perform surgical removal of tonsils, a doctor that administered anesthesia during the procedure, and an orderly to maintain the surgical area. Postoperatively, Lamb would monitor the children until they recovered from surgery. At this point, the children spent the night in the school with a parent to complete their recovery period. ${ }^{219}$

The National Conference on Fundamental Problems in Negro Education summarized in 1934 that the needs of child health education of blacks included: 1) integrated health courses for teachers, 2) equitable financial support and service in health problems, 3) more modern school houses, 4) health education focused on health habits taught in every school, 5) facilities to train black patients and train black nurses, 6) employment of more black doctors and public health nurses on staff, 7) proper sanitation in cities and rural areas to eliminate slums and malariainfested districts, 8) increased awareness by blacks of the need for healthy habits, 9) continued control and prevention of infectious diseases, and 10) coordination of agencies in projecting extensive programs for the well-being of black children. ${ }^{220}$

Health education programs in these areas for teachers, however, were developed with little influence from nursing. The programs built on existing health content from biology, 
chemistry, psychology, home economics, physical education and hygiene. Health education for teachers allowed the teachers to bring daily health and sanitation education to students who had limited access to doctors and nurses. The daily activities of the school house became the model to demonstrate to children the practices and value of proper health and hygiene practices using songs that addressed health habits, encouraging use of individual drinking cups, appointed monitors to supervise appropriate heating and ventilation of classrooms, maintaining a Health Note Book, and parent meetings to acquaint them with the health education program. ${ }^{221}$

Rosenwald Funds contributed to an epidemiologic study in Tennessee evaluating the mortality rates of tuberculosis in black and white rural and industrial communities. The epidemiologic studies revealed that poor environmental conditions in rural communities contributed significantly to the higher mortality differentials between blacks and whites. The outcome was increased focus in two area: 1) state and local health departments addressing environmental factors and 2) health education programs in rural black schools. Ongoing evaluation of effectiveness was done via survey of students in conjunction with home inspections using a 29 question Health Habit Questionnaire. ${ }^{222}$

In an interview discussing her public health nursing experiences, Nurse Fisher addressed the alliance with teachers in school health education. Because of the overwhelming clinical responsibilities of school nurses like Fisher, the daily responsibility of teaching children health habits needed to rest with the teachers. Fisher describes her public health nursing routine:

Dr. King and I spent most of our time in the field. In the summertime we had massive typhoid and smallpox immunization clinics. In the winter we visited the schools there were fifty schools!...Dr. King would do the physical examinations and I would weight and measure the children, and check their vision. The teacher (most of the schools were one-room) would help with the records. And that was how we spent most of our days in the winter because it took a long time to get around to all the places. ${ }^{223}$ 
Conclusion

Collaboration and education were imperative to overcome the environmental factors that impeded adequate health for rural blacks. The complementary relationship between black and white nurses was not unlike the collaborations encouraged by Booker T. Washington and Julius Rosenwald. Although Washington's call for educational self- help rather than political activism was viewed by Du Bois and others as accommodating to racial prejudice, in health care there were some gains. Black nurses worked primarily with black families and schools to promote education around proper health and sanitation practices, and white nurses participated in supervisory and statewide programs that enforced the consistency and effectiveness of public health activities across the state. Both roles were instrumental in the improvement of the health of the black community.

Both federal and private funds increased the nursing workforce that allowed better access to care for blacks. White nurses became an unintended ally for black nurses and lay midwives, facilitating midwife education and giving these black women the opportunity to continue to practice. Through their participation and collaboration in statewide education improvement efforts, white nurses contributed to improvements in health, education and economic development in the state.

\footnotetext{
${ }^{177}$ Phoebe Pollitt, The History of Professional Nursing in North Carolina: 1902-2002 (Durham: Carolina Academic Press, 2014).

${ }^{178}$ George M Cooper, "A state program of school health in North Carolina," Public Health Nursing (1934): 90-93.
} 
179

${ }^{180}$ North Carolina Board of Health, A History of the North Carolina Board of Health (1966), Raleigh, NC: North Carolina Board of Health.

${ }^{181}$ Pollitt, The History of Professional Nursing in North Carolina.

${ }^{182}$ Carl Reynolds and Lucy Morgan, "North Carolina moves toward health education for All People," The High School Journal (1947): 118-120.

${ }^{183}$ Mary Lewis Wyche, The History of Nursing in North Carolina (Chapel Hill: University of North Carolina Press, 1938).

${ }^{184}$ Holly Matthews, "Killing the Medical Self-Help Tradition Among African Americans: The Case of Lay Midwifery in North Carolina, 1912-1983," in African Americans in the South: Issues of Race, Class, and Gender (Athens and London: The University of Georgia Press, 1992), 60-78, quote p. 65.

185 Judith Walzer Leavitt, Brought to Bed: Childbearing in America, 1750-1950 (New York: Oxford University Press, 1988).

${ }^{186}$ Oral history with Anne Eliza Lamb by Jane Plyler, November 20 and December, 1979; Clinton, North Carolina.

${ }^{187}$ Matthews, "Killing the Medical Self-Help Tradition," 66.

${ }^{188}$ P Kernodle, The Red Cross Nurse in Action: 1882-1948 (New York: Harper and Row, 1949).

${ }^{189}$ Avery County Red Cross, The Avery Advocate (1928), 1.

${ }^{190}$ Ibid

${ }^{191}$ Oral history with Amy Fisher by Jane Plyler, October 4, 1977; Mount Pleasant, North Carolina.

${ }^{192}$ Fisher oral history.

${ }^{193}$ Johanna Schoen, Choice \& Coercion: Birth Control, Sterilization, and Abortion in Public Health and Welfare (Chapel Hill \& London: The University of North Carolina Press, 2005).

${ }^{194}$ James Leloudis, "School Reform in the New South: The Woman's Association for the Betterment of Public School Houses in North Carolina, 1902-1919," The Journal of American History 69, no. 4 (1983): 887.

${ }^{195}$ Leloudis, "School Reform."

${ }^{196}$ John Hunter, "Tuberculosis in the Negro: Causes and Treatment," Colorado Medical Journal (1905): 250-252, 254-257.

${ }^{197}$ Ibid

${ }^{198}$ J. Scott McCormick, “The Julius Rosenwald Fund,” Journal of Negro Education (1934): 605. 
${ }^{199}$ Booker T. \& W.E.B.: The debate between W.E.B. Du Bois and Booker T. Washington. "The Two Nations of Black America." PBS, Frontline. Accessed 1/18/16 at:

http://www.pbs.org/wgbh/pages/frontline/shows/race/etc/road.html

${ }^{200}$ Daniel Aaronson and Bhashkar Mazumder, "The Impact of Rosenwald Schools on Black Achievement," Journal of Political Economy 119, no. 5 (2011): 821-888.

${ }^{201}$ McCormick, "The Julius Rosenwald Fund," 605.

${ }^{202}$ McCormick, "The Julius Rosenwald Fund."

203 Thomas Hanchett, "The Rosenwald Schools and Black Education in North Carolina." The North Carolina Historical Review (1988), 387-427.

${ }^{204}$ Phoebe Pollitt and Camille Reese, "School nursing in North Carolina: From New Idea to the New Deal, Part 2," American Association for the History of Nursing Bulletin (1997): 7-9.

${ }^{205}$ Winfred Nathan, "Health Education in Negro Public Schools," The Journal of Negro Education 6 (1937): 529.

${ }^{206}$ Nathan, "Health Education."

${ }^{207}$ Nathan, "Health Education."

${ }^{208}$ Nelson Harris, "The Education of Negroes in North Carolina," The Journal of Negro Education (1947): 387-396; Hanchett. "The Rosenwald Schools."

${ }^{209}$ Aaronson and Mazumder, "The Impact of Rosenwald Schools."

${ }^{210}$ Nelson Harris, "The Education of Negroes in North Carolina."

${ }^{211}$ Ibid

212 Ibid

${ }^{213}$ Harris, "The Education of Negroes in North Carolina."

${ }^{214}$ Harris, "The Education of Negroes in North Carolina."

${ }^{215}$ Max King, “The Negro Health Problem,” The Health Bulletin 54, no. 3 (1939): 10.

${ }^{216}$ Pollitt, The History of Professional Nursing.

${ }^{217}$ Pollitt, The History of Professional Nursing.

${ }^{218}$ Wyche, The History of Nursing in North Carolina.

${ }^{219}$ Plyler, Public Health Nursing in North Carolina. 
${ }^{220}$ Nathan, "Health Education."

${ }^{221}$ S. Smith, "Development of a Health Education Program for Negro Teachers," The Journal of Negro Education (1937): 538-547.

${ }^{222}$ Smith, "Development of a Health Education Program."

${ }^{223}$ Fisher oral history. Fisher does not list Dr. King's first name, although it likely was not Dr. Max King, black president of Old North State Medical Society. 


\section{Chapter 5: CONCLUSION}

The nation's public health infrastructure, and the nursing care provided within this system, has been directly impacted by the growth and evolution of public health nursing professionals. Public health nurses, both black and white, crossed class and race lines to provide care for some of the sickest members of the community in some of the least desirable environments. New public health policies and programs would not have been effective without the relationships built, trust earned, daily sacrifices, commitment and planning of public health nurses.

Black women in nursing have long fought multiple battles in their advancement as nursing professionals since the early 1900s. Many were drawn to nursing out of a need to 'help their people,' to improve the health of the black community. Indeed in the emerging professions for women, nursing for black women was at the top of the hierarchy. In working among their black communities, these women were seen as role models, and became major active forces for change.

This battle could not be fought without simultaneously addressing the struggles of black women in a time of race and gender discrimination. Despite racism, poverty, and disenfranchisement, black nurses' abilities to positively impact the health of their communities were significant. They stepped up to the challenges presented to them at the time, fostering growth professionally as well as being a vital force in the social progression of the race. They used the limited educational opportunities available, worked for lower pay than their white 
counterparts, sought out the employment opportunities available to them, and created deep and nurturing relationships in their community in order to share vital health information.

Black nurses' position within the community was irreplaceable. They were the translators, motivators, and mediators between patients and physicians. Health information relayed during the all too infrequent encounters with an already short supply of white physicians were often misinterpreted by their patients because of the educational and cultural gaps between them. But the black nurse, who had established trust and respect within the community, was able to bridge these gaps. Black nurses were more readily available to rural communities and were often the only source of health care to many blacks during this time. While some white nurses were able and willing to provide care to the black community, cultural gaps and issues of mistrust remained a barrier to adequate nursing care of this vulnerable community. Black nurses were uniquely qualified to meet the needs of black patients in the rural South and showed dedication and determination in their efforts to grow stronger and more effective as professionals.

Some white nurses worked to improve the health of the black community through community partnerships, relationship building, and development of public health policies that provided better care to rural communities. In working with lay midwives to standardize the care and education they provided, white nurses inadvertently gave credibility to this group of lay providers and allowed them some added tenure in the South before they were almost completely eliminated some 20 to 30 years later. While some viewed white nurses as taking part in the racially charged elimination of black lay midwives, one could also argue that, in the 1920s and 1930s, some white nurses' roles as liaison between black lay midwives and white physicians was crucial to allowing some sort of compromise between the two groups. 
Equally important was the black nurse's ability to look beyond assumptions of genetic inferiority as reasons for illness in the black community. These nurses addressed issues of education, sanitation, and class as potential barriers to good health. While some may have viewed black nurses as outwardly accommodating to their situation, this view fails to see them as respected activists in their own communities. A commonly held theory among black public health officials of this time was that environment was a significant predisposing factor to poor health. Therefore, black nurses, in partnership with community groups, were able to positively impact the health of blacks through targeted health and sanitation education and preventive nursing care. The foundation of the black public health awareness campaign was education and empowering the community to attain better health through understanding of the power to change some of the social determinants of health.

Place mattered when it came to quality care and improved health outcomes for black families. In the social climate of racial tensions and disenfranchisement, health education and preventive care was crucial but not easily accessible for blacks. Black families relied on informal structures of care like root workers and lay midwives. Despite the fact that lay midwives were untrained and care was inconsistent, for the most part they were trusted, readily available, and had comparable outcomes considering the very unfavorable environmental circumstances of poor rural families. Black lay midwives were valued and earned trust because they did not turn away patients based on skin color or ability to pay. They earned trust because of their willingness to go where care was needed.

Relationship building was another vital factor in effective care for black families. Black families needed someone they could trust to listen to their concerns and teach them what they needed to know about their health. For most blacks, that trust was more readily shared with 
someone that looked like them or seemed to genuinely care about their well-being. Many black nursing leaders argued that having more black nursing and medical providers was key in improving health in the black community.

Community building was a necessary contribution of both black and white nurses. Nurses willing to come to schools and educate black children, or go to churches and teach during bible study classes were the ones who earned the trust and became a member of the community. Willingness to become a part of the community showed dedication and commitment—both important prerequisites for trust. White nurses working in the black community also earned trust because they made sacrifices of their time travelling to remote regions and showing up consistently. Nurses like Anne Lamb whose arduous travel to the most remote regions of the state was the means for delivery of valuable public health screening and education, both in the homes and in the schools. Care needed to take place in tobacco fields, at kitchen tables, in schoolhouses, and in Sunday school classrooms. The community was important for the survival of a disenfranchised group of people who relied heavily on one another.

The culprits of ill health were controllable environmental factors: poverty and poor sanitation, poor education, and lack of maternal/infant care. In order to address these factors, the nurses had to join forces with a multidisciplinary team prepared to address these social ills. Sanitarians tackled the water quality issues by first implementing a system for proper waste disposal and distributing privies throughout rural communities for safe containment of waste. Nurses like Edith Holmes and Elizabeth Thompson were then able to capitalize on the CWA workers' massive privy production and distribution and convince everyday residents to actually utilize these new facilities properly. 
In order to address the need for health education for families, public health officials turned their focus on the children. The health departments sent nurses to the schools for health education and immunizations to decrease mortality from infectious diseases. Teachers' colleges restructured teaching curricula to incorporate health education for prospective teachers. And public health nurses addressed the concern of inadequate, inconsistent, and unskilled care for mothers and their newborns by supervising care given by lay midwives. Federal funding through programs such as Sheppard-Towner helped subsidize these programs. Indeed, nurses' work with midwives had far reaching impact on the families across the state, addressing maternal/infant mortality and creating healthier babies.

Black families in North Carolina needed to have a voice in the public health planning and implementation process, and federal funding helped increase the number of black public health nurses. Perhaps their voice was most powerful in the community health education programs implemented nationwide, like National Negro Health Week, where black nurses identified their own needs from within the community and developed programs that were implemented in a mass public health awareness movement. Another key contribution of black nurses was the training and standardization of black lay midwives. Black nurses were uniquely positioned to bring their health expertise to the conversation of racial uplift and community rebuilding. The contributions of this group of health professionals during an era when they were so marginalized are indeed valuable. In the 1980s, when state legislation eliminated lay midwives, officials began to suggest that local workers be recruited to teach rural women about pregnancy and childbirth. ${ }^{224}$ They could look to public health nurses of the 1920s and 1930s as examples. 
${ }^{224}$ Holly Matthews, "Killing the Medical Self-Help Tradition Among African Americans: The Case of Lay Midwifery in North Carolina, 1912-1983," in African Americans in the South: Issues of Race, Class, and Gender (Athens and London: The University of Georgia Press, 1992), 60-78. 